\title{
Impacts of climate change on stream flow and hydro power generation in the Alpine region
}

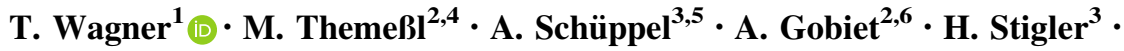 \\ S. Birk ${ }^{1}$
}

Received: 28 July 2016/Accepted: 3 December 2016/Published online: 19 December 2016

(C) The Author(s) 2016. This article is published with open access at Springerlink.com

\begin{abstract}
Electricity generated by hydro power is the most widely used form of renewable energy, and as such, its vulnerability to climate change is of great interest. The aim of this work is to estimate the change in river discharge characteristics in the Alpine region due to possible impacts of climate and the related changes in the power generation of run-of-river hydro power plants up to 2050. Four representative bias-corrected climate simulations from the ENSEMBLES project are chosen based on the SRES greenhouse gas emission scenario pathway A1B. Data of these simulations serve as input for a lumped-parameter rainfall-runoff model at a monthly time step, which is calibrated on discharge data of gauging stations along important rivers in the Alpine region. A power plant model fed with runoff data generated by the hydrological model is used to compute changes in the long-term average annual
\end{abstract}

T. Wagner

thomas.wagner@uni-graz.at

1 Institute of Earth Sciences, NAWI Graz Geocenter, University of Graz, Heinrichstrasse 26, 8010 Graz, Austria

2 Wegener Center for Climate and Global Change, Brandhofgasse 5, 8010 Graz, Austria

3 Institute of Electricity Economics and Energy Innovation, TU Graz, Inffeldgasse 18, 8010 Graz, Austria

4 Present Address: Climate Change Center Austria Servicezentrum, Krenngasse 37/1, 8010 Graz, Austria

5 Present Address: Elsta-Mosdorfer GmbH, Bahnstraße 29, 8430 Kaindorf an der Sulm, Austria

6 Present Address: ZAMG - Zentralanstalt für Meteorologie und Geodynamik, Klusemannstr. 21, 8053 Graz, Austria net electrical energy output of hydro power plants for the whole Alpine region; while the model for Austria is based on known technical parameters of the power plants, a more simplified approach is employed elsewhere. The general warming trend observed in all four climate scenarios causes to various degrees a seasonal shift towards earlier runoff. However, more diverse changes in precipitation for the different climate scenarios and time periods result in diverging hydrological projections. Although the annual runoff is found to decrease in some scenarios, the generally observed shift of runoff towards the winter season that typically shows higher energy consumption in the Alpine region suggests that the overall impact for the electricity sector tends to be positive rather than negative. Estimated changes in the average annual electricity generation of runof-river plants are generally found to be within a singledigit percentage range but can be either positive or negative depending on the climate scenario. The estimated ranges reflect the diversity (uncertainty) of the climate models; the total bandwidth of possible changes in the water availability and hydro power generation in the Alpine region up to 2050 is assumed to be even higher, because of other uncertainties in the model chain that are not explicitly considered here. Nevertheless, as the general regional trends and bandwidth of changes in runoff and hydro power production strongly depend on the future changes in precipitation, the results of this work provide reasonable orders of magnitude of expected changes and are seen as a first step towards an improved understanding of climate impacts on hydro power production within the entire Alpine region.

Keywords Climate change - Rainfall-runoff modelling · Hydro power - Renewable energy - Alpine region 


\section{Introduction}

The Alpine climate, its long-term changes induced by increasing greenhouse gas concentrations in the atmosphere, and the influence of climate change in the Alps on various natural and socio-economic sectors have been intensively investigated in the last decades (e.g. Haeberli and Beniston 1998; Schär et al. 1998; Beniston and Jungo 2002; Raible et al. 2006; Auer et al. 2007; OECD 2007; Brunetti et al. 2009). For example, the EU Green Paper (2007) on adaptation to climate change in Europe as well as the EEA report (2012) states that the Alps are amongst the most vulnerable areas in Europe.

From the late nineteenth to the end of twentieth century, the Alps have warmed at a rate about twice as large as the average northern hemisphere, resulting in an increase in mean annual temperature of about $+2{ }^{\circ} \mathrm{C}$ (Auer et al. 2007; Brunetti et al. 2009; Kromp-Kolb et al. 2014). The intensity and frequency of precipitation is changing too, but the sign and magnitude of changes depend on the region and season (e.g. Brunetti et al. 2006, 2009). In future, the temperature is expected to continue to increase and the seasonality of precipitation (more in winter and less in summer) is expected to change (Gobiet et al. 2014). In particular, the intensity and frequency of extreme precipitation events is expected to increase (Rajczak et al. 2013; Gobiet et al. 2014). Several case studies (e.g. Klein et al. 2011; Farinotti et al. 2012; Laghari et al. 2012; Kobierska et al. 2013) have shown that the expected future changes will alter the runoff dynamics of rivers in the Alpine region. The potential impact of such hydrological changes on hydro power production is evident, but quantitative assessments are rare. The possible effects on Europe's hydro power potential were analysed by Lehner et al. (2005) at the country scale using a global water model driven by climate change projections from General Circulation Models. At smaller scale, more detailed analyses of single hydro power plants or individual catchments of the Alpine region are available (e.g. Schaefli et al. 2007; Koch et al. 2011; Maran et al. 2013; Bongio et al. 2016; Majone et al. 2016). To our knowledge, however, a consistent catchment-scale assessment of climate change impacts on hydro power generation within the entire Alpine region is still lacking (e.g. based on a recent review of Schaefli 2015).

This paper aims to provide a first assessment of the impact of climate change on stream flows and consequently on the hydro power generation of run-of-river plants based on a scheme-scale analysis in the entire Alpine region up to the year 2050. It builds on results of the project EL.ADAPT (Impacts of Climate Change and Adaption in the Electricity Sector-The Case of Austria in a Continental
European Context), which addressed climate change impacts on the Austrian electricity sector in general (Bachner et al. 2013). While this project integrated various different models applied to various areas within Europe, the focus here will be on the hydrological and hydro power modelling approaches and their application to the Alpine region. Nevertheless, a consistent data set was chosen that covers whole Europe. Due to resource and time constraints, the number of climate change scenarios was limited to a selection of four that cover a broad range of possible future changes roughly representing the bandwidth of the entire available model ensemble (Bachner et al. 2013). Yet, it should be noted that the selected scenarios-just as any other multi-model ensemble-represent an "ensemble of opportunity" (Tebaldi and Knutti 2007), which is not designed to cover the full range of uncertainty.

The relatively large study area, its topographic complexity as well as data availability ask for relatively simple, yet effective structures of the hydrological and hydro power models. For the periods 1961-1990 (historical reference period), 2011-2030, and 2031-2050, expected changes in the discharge characteristics of 101 (sub-) catchments are analysed using a rainfall-runoff model on a monthly time step driven by precipitation and temperature obtained from the four selected high-resolution climate scenarios. In addition, a hydro power plant model is used to account for the known technical parameters of the individual run-of-river plants (where available) and for the size of their actual catchment areas, which might differ from those of the stream gauges considered by the hydrological model. This approach is consistently applied within the entire Alpine region and thus allows drawing first conclusions on the total magnitude and spatial variation in potential climate change impacts on stream flow and electricity generation of run-of-river plants. Although there are inherent uncertainties in the hydrological as well as the hydro power model that are hard to quantify directly, it is attempted here to identify potential sources of uncertainty such as potentially non-stationary processes that are not explicitly or only in a simplified way considered by the model (e.g. evapotranspiration, glacier melt) and thus to assess the general trends in the future runoff and hydro power production. The results, on the one hand, help to identify further research needs and, on the other hand, provide order of magnitude estimates of changes in runoff and hydro power production at the regional scale within the entire Alpine region.

\section{Data sets and methods}

Various meteorological, hydrological, and hydro power plant-related data sets need to be compiled, processed, and analysed to allow considering possible future changes in 
the model chain climate-river runoff-hydro power generation. Although this is a rather classical impact framework, it appears to be the first scheme-scale analysis for hydro power generation covering the entire Alpine region. As such, a compromise of data needs and data availability had to be found, which will be described in the following.

\section{Climate scenarios and observations}

In order to provide meteorological input (temperature and precipitation amount) for the hydrological model in the Greater Alpine Region (GAR; see Fig. 1), four carefully selected (see below) regional climate model (RCM) simulations from the ENSEMBLES project (van der Linden and Mitchell 2009) were used. Within ENSEMBLES, 23 RCM simulations are available based on 8 different global climate model (GCM) simulations. They are operated at a horizontal resolution of $25 \mathrm{~km}$, which was the highest resolution available covering the entire region and period of interest at the time when this study was conducted. Recently, a new set of regional climate simulations for Europe became available from the EURO-CORDEX initiative (Jacob et al. 2013). These regional climate simulations are downscaling the new CMIP5 global climate projections (Taylor et al. 2012) and the new representative concentration pathways (RCPs) (van Vuuren et al. 2011). Comparisons of EURO-CORDEX results given in Jacob et al. (2013) and Kotlarski et al. (2014) suggest that the model performance for large-scale patterns of changes in mean temperature, precipitation, and related indices in the EURO-CORDEX simulations is similar to those of ENSEMBLES.

The ENSEMBLES RCMs provide daily time series from 1951 to 2050 and are based on the SRES greenhouse gas emission scenario A1B (Nakicenovic et al. 2000). A1B is a moderate emission scenario, but features no large differences to other emission scenarios up to 2050 in its consequences to climate change (e.g. Prein et al. 2011). However, after 2050 these differences become important and a single emission scenario might not be appropriate to cover the bandwidth of possible long-term climate change in the Alpine area. In total, 19 out of 23 ENSMBLES models entered the scenario selection process; four were disregarded due to technical and availability reasons at the time of the study. Four representative climate simulations were chosen that cover the bandwidth of climate change of the entire ENSEMBLES multi-model data set (see Bachner et al. 2013, p. 7-14 for details), and range from hot-dry over moderate to humid-warm-thus, it is expected that relevant climate change conditions for impacts on the hydrological and power generation systems are considered in this study. Although changes in wet or dry spells or similar extreme indicators were not taken into account for model selection, the spread of the selected scenarios can be regarded as representative for model uncertainty within the
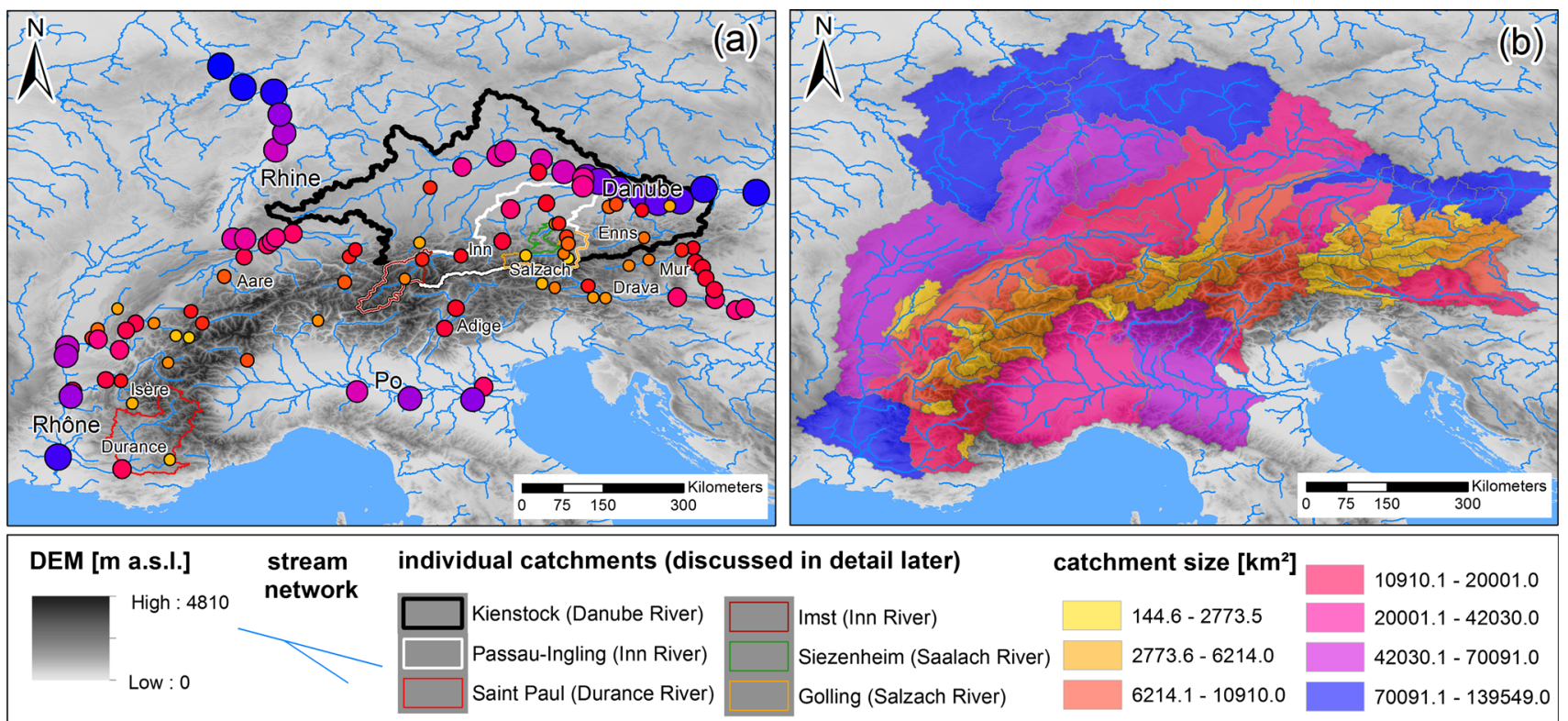

Fig. 1 Study area of the Greater Alpine Region (GAR), important rivers and gauging stations used; a distribution of gauging stations on top of a digital elevation model (DEM) of the Alpine region; individual gauging stations and their related catchments discussed in more detail in the following are depicted; b catchments of the considered gauging stations covering the Alpine arc, note that smaller (sub-)catchments superpose larger catchments; hence the colourcoding according to the actual size of the individual catchments. Colour-coding is consistent in $(\mathbf{a}, \mathbf{b})$ 
A1B scenario as demonstrated by Heinrich et al. (2014). For a more detailed description of the selection process, see Bachner et al. (2013). The selected model \#1 (Meteo-HC HadRM3Q0) features a very warm and dry climate change signal in summer, and mild conditions in winter. This scenario is considered to result in overall positive effects on the electricity system, due to an expected decline of residual load in winter, although the residual load will slightly increase in summer. However, for hydro power generation, these very warm and dry conditions should yield rather negative effects. Thus, model \#1 will be termed "warm-dry" scenario from now on. Model \#2 (C4IRCA3) features a very wet and warm climate change signal (CCS) in both summer and winter. It will be termed "humidwarm" scenario. Model \#3 (CNRM-RM4.5) features the special case of a stronger summer than winter warming. According to its expected effect on the electricity system, model \#3 will be termed "warm-summer" scenario. Model \#4 (KNMI-RACMO2) represents more or less an average realization of all 19 considered RCMs. Precipitation is shifted towards winter season, the overall precipitation during the year changes insignificantly. This scenario was chosen as an average scenario, because it does not comprise any outstanding precipitation CCS. It will be termed "moderate" scenario in the following, because the expected effects on the electricity system are moderate in total.

Temperature and precipitation of the selected RCMs have then been bias-corrected independently on daily basis, applying quantile mapping (QM) as described in Themeß1 et al. (2011, 2012) and Wilcke et al. (2013). For bias correction, the E-OBS European gridded observational data set (Haylock et al. 2008; van den Besselaar et al. 2011) was used. Wilcke et al. (2013) showed that these corrections (applied in this study) retain the inter-variable dependencies of RCMs and therefore do not add additional uncertainty for further impact assessments in this respect. E-OBS contains gridded daily time series of mean, minimum, maximum air temperature $\left({ }^{\circ} \mathrm{C}\right)$, and precipitation amount $(\mathrm{mm} /$ day) on a $25-\mathrm{km}$ grid and is based on the most complete freely available collection of station data over wider Europe (Klok and Klein Tank 2009). A similar data set for global radiation and wind speed does not yet exist for entire Europe and is-amongst other things discussed later in the text-a reason why a simple hydrological model has been chosen that needs only temperature and precipitation as meteorological input.

\section{Hydrological modelling}

The purpose of the hydrological model within the model chain is to estimate the impacts of climate change on the discharge characteristics of rivers within the Alpine region at a monthly time step. In other words, a simple yet effective model has been chosen that converts precipitation to stream flow in catchments of variable size and topography by means of temporal storage and delay of precipitation. For model calibration and validation, discharge time series of 101 gauging stations in Austria, Germany, Slovenia, France, Italy, and Switzerland, which were provided by various organizations (see "Acknowledgements"), were compiled. The length of the time series ranges from 10 to 60 years, and the size of the catchments related to the gauging stations ranges from $150 \mathrm{~km}^{2}$ to more than $100,000 \mathrm{~km}^{2}$ (see Fig. 1). Some of the data were available as monthly runoffs only, some also as daily runoffs. As meteorological input for calibration and validation, the E-OBS data set described in "Climate scenarios and observations" section was used.

Since the hydrological model needs to be applicable for a wide region as well as various catchment sizes and should operate with only precipitation and air temperature as input data, the parsimonious lumped-parameter model GR2M (Perrin et al. 2001, 2003; Mouelhi et al. 2006; Okkan and Fistikoglu 2013, Wagner et al. 2013) has been selected and extended by a snow model that accounts for snow storage and melt based on temperature only (as proposed by $\mathrm{Xu}$ et al. 1996). Potential evapotranspiration (PET) is computed based on the formulation of Oudin et al. (2005), as only temperature is available as input parameter here. In addition to temperature, extraterrestrial solar radiation is needed for the computation of the PET. Following Oudin et al. (2005), extraterrestrial radiation depends on the geographical position of the catchment and the time of the year as it exhibits a seasonal variation but is assumed to remain constant over the years (data taken from http:// www.cgiar-csi.org).

A schema of the model structure is shown in Fig. 2. The approach is based on a spatial, temporal, and conceptual lumping which is considered to be a suitable model structure for the purpose of monthly rainfall-runoff prediction due to its parsimony and the limited information content of discharge time series available for calibration and validation (Edijatno et al. 1999; Perrin et al. 2001; Gupta et al. 2005). A monthly time step has been considered most appropriate because of (1) computational efficiency, (2) an accepted capability of monthly rainfallrunoff models to simulate runoff with relatively few parameters (e.g. Mouelhi et al. 2006), and (3) the fact that long historical time series of flow data are consistently available on a monthly time step; generally, daily time step flow data are likely related to more uncertainty and often include larger data gaps (e.g. Smakhtin 2000). Moreover, monthly runoff data provide sufficient input for the subsequent step in the model chain, as for most of the hydro power plants considered in the hydro power model (except 


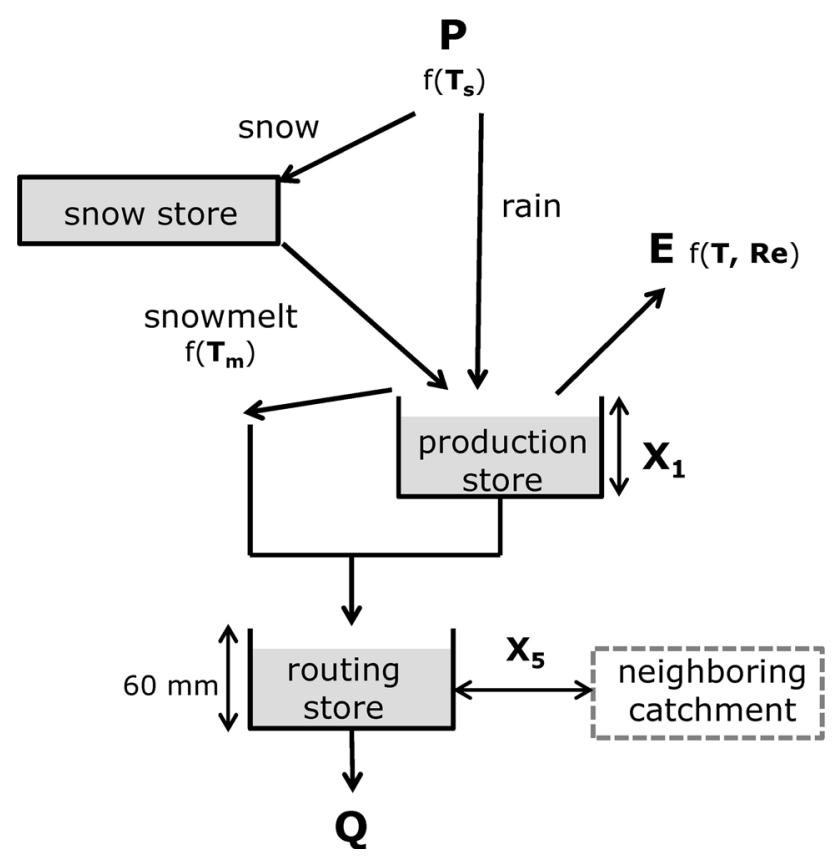

Fig. 2 Structure of the hydrological model (GR2M+)

for the Austrian hydro power plants) only monthly data were available.

Processes accounted for are snow storage and snow melt, evapotranspiration, soil water storage represented by a soil moisture accounting store (=production store as used in Mouelhi et al. 2006), groundwater storage (=routing store as used in Mouelhi et al. 2006), and water exchange with neighbouring catchments (intercatchment flow; Wagner et al. 2013). There are in total four free (to be calibrated) parameters in the model (in the following called GR2M+): a critical temperature $T_{\mathrm{S}}$ below which snowfall starts and adds to the snow store; a critical temperature $T_{\mathrm{M}}$ above which snow melt starts and decreases the snow store; the maximum capacity $X_{1}$ of the production store; and a groundwater exchange term $X_{5}$, which accounts for water flow to $\left(X_{5}>1\right)$ or from $\left(X_{5}<1\right)$ neighbouring catchments. Such a parameter has been shown to be important, as groundwater flow from or to a neighbouring catchment is often observed and the discharge measured at stream gauges does not take into account groundwater flow within the alluvial aquifer accompanying the stream (Mouelhi et al. 2006; Le Moine et al. 2007; Wagner et al. 2013). However, the routing store (accounting for groundwater storage) is held constant $(60 \mathrm{~mm}$; representing a quadratic reservoir), which is a necessary simplification due to the unavailability of detailed local data of groundwater flow, but was shown by Mouelhi et al. (2006) to be effective.

As was pointed out by Gupta et al. (2005), the information content of a runoff time series is limited and a model with only a few free parameters avoids the issue of equifinality. Although incorporating additional processes into the hydrological model is appealing, it bears the risk that the model is overparameterized (Loague and Freeze 1985; Beven 1989; Perrin et al. 2003; Wagner et al. 2013). To demonstrate that the above-described model is able to adequately reproduce the runoff behaviour observed in the past, historical area-weighted average monthly temperature and precipitation data (based on the E-OBS v4 data set) are computed for the individual catchments and used as forcing input in the model. The simulated runoff is compared to the observed runoff from the individual stations, and the four free parameters are optimized to yield a minimum difference between observed and simulated runoff based on three objective functions: (1) the classical Nash-Sutcliffe efficiency criterion (Nash and Sutcliffe 1970), (2) the NashSutcliffe criterion calculated on the square-root-transformed stream flow, and (3) the Nash-Sutcliffe criterion on the logarithm-transformed stream flow (Perrin et al. 2003; Wagner et al. 2013, 2016). The classical Nash-Sutcliffe criterion focuses on optimizing peak flows, the one based on logarithm-transformed stream flow focuses on low flows and the one based on square-root-transformed stream flow gives an intermediate picture of the overall hydrograph fit (e.g. Oudin et al. 2006). In the following, the combined efficiency criteria will be termed $\overline{\mathrm{NSE}}$ as their value is given as an average number of the three criteria (equal weights) to have the same value range as the individual criterion $(-\infty$ to 1$)$. The optimization of GR2M+ is performed using the Excel Solver.

To evaluate the predictive capability of the model, the model was calibrated using the first half of the data set and validated using the second half and vice versa (split sample test; Klemes 1986). At least one year of warm-up period was assigned to minimize the effects of the initial conditions. An example of a calibrated hydrograph including a split sample test is shown in Fig. 3a using the example of the gauging station Kienstock along the River Danube (catchment size of $95,970 \mathrm{~km}^{2}$; see Fig. 1a for location of the catchment). It is noteworthy that if the model is calibrated using the first half of the time series (1661-1985; $\overline{\mathrm{NSE}}$ of $74.9 \%$ ), it is able to simulate the runoff for the second half (1986-2010) rather good ( $\overline{\mathrm{NSE}}$ of $79.1 \%)$, even the low flow during the drought period in 2003.

Hence, model validation is based on different efficiency criteria (trade-off in single efficiency criteria to have an overall consistency; the "closeness" of simulated and observed stream flow; Krause et al. 2005), visual inspections of the hydrographs, and split sample tests. This evaluation was done for the whole data set of 101 measurement stations. The average of the three efficiency criteria $(\overline{\mathrm{NSE}})$ for all the stations yielded $78.9 \pm 6.8 \%$ when calibrated for the whole time period, and when validated on 


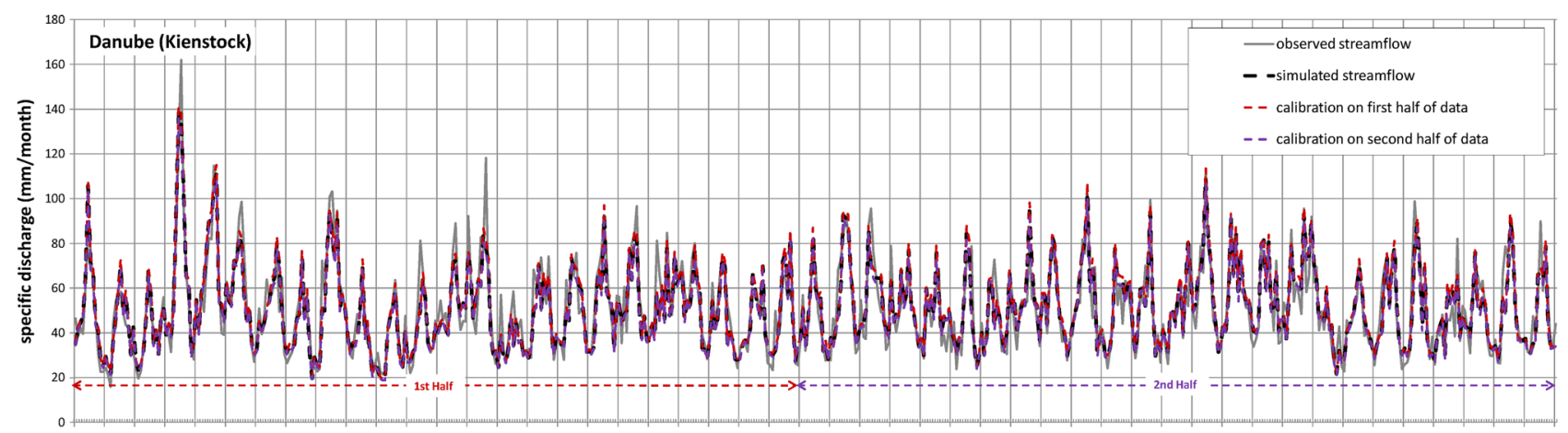

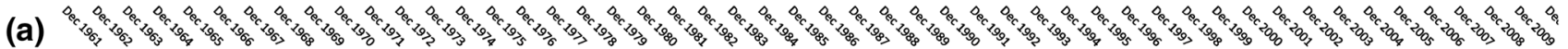

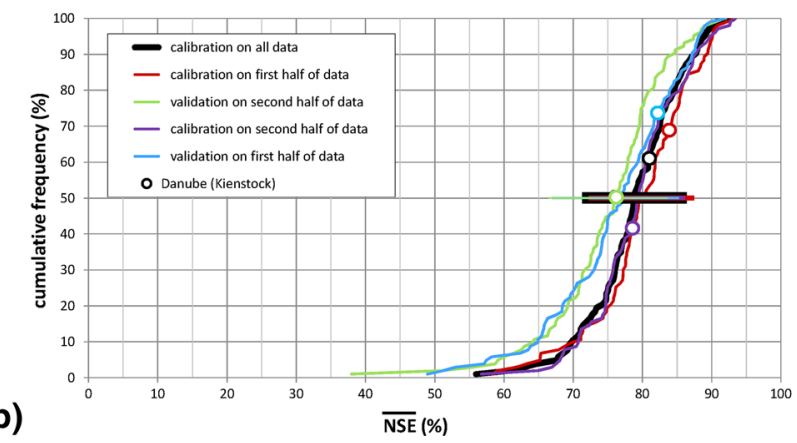

(b)

Fig. 3 Efficiencies of the hydrological model. a Hydrograph of the gauging station Kienstock (Danube River, $95,970 \mathrm{~km}^{2}$ ): observation data $=$ grey line, calibration using the whole time span = black dashed line $(77.2 \% \overline{\mathrm{NSE}})$, calibration using the first half of data $=$ red dashed line $(74.9 \% \overline{\mathrm{NSE}}$; validation on second half of data: $79.1 \% \overline{\mathrm{NSE}}$ ) and calibration using second half of data = violet dashed line $(80.0 \% \overline{\mathrm{NSE}}$; validation on first half: $74.2 \% \overline{\mathrm{NSE}})$; b

one half of the time series after calibrating it on the other half of the time series $75.1 \pm 8.5$ and $76.1 \pm 9.0 \%$, respectively (Fig. 3b). Mouelhi et al. (2006) reported an average Nash-Sutcliffe efficiency criterion of $64.2 \%$ for the 410 catchments they analysed, indicating that our results are comparatively good. According to the classification of Nash-Sutcliffe efficiency criteria proposed by Moriasi et al. (2007), nearly all of the calibrated models are rated as "good" $(>65 \%)$ or "very good" $(>75 \%)$. Moreover, there is no correlation of model efficiency and catchment size, which suggests that the simple model is able to reproduce stream flow for a wide range of catchment sizes (Fig. 3c).

However, seasonality in discharge time series can produce relatively high NSE values; therefore, a benchmark approach as proposed by Garrick et al. (1978) and later by Schaefli and Gupta (2007) was followed for some of the catchments analysed. The applied model performs superior to the benchmark model (assuming interannual mean monthly runoff values; Schaefli and Gupta 2007); however, for individual catchments, the improvement is small, indicating that seasonality plays an important role in the discharge behaviour of these catchments (e.g. station

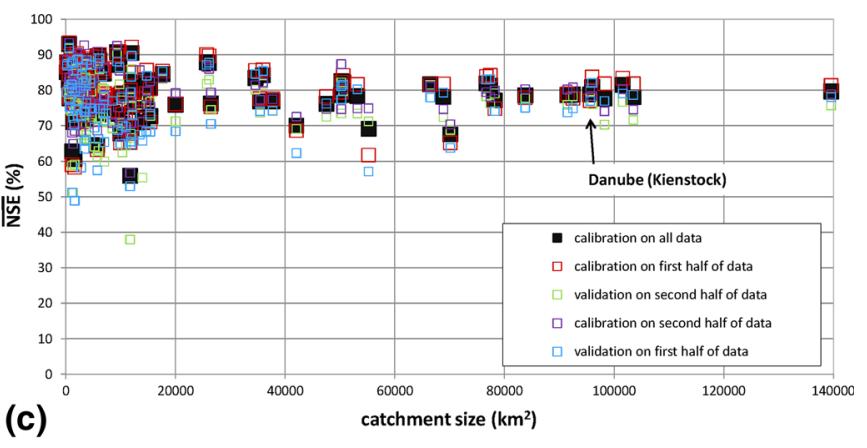

cumulative frequency distribution of model efficiencies ( $\overline{\mathrm{NSE}})$ for all catchments considered. Note that for model validation, the efficiencies are for the most part in acceptable ranges $(\geq 65 \%)$ or even good $(\geq 80 \%)$. As an example, the efficiencies of the gauging station Kienstock shown in Fig. 3a are displayed (round symbols); c $\overline{\mathrm{NSE}}$ efficiency criteria versus the catchment sizes of the stations analysed

Golling along the Salzach River). Nevertheless, this is an expected fact of monthly runoff data of alpine catchments.

In addition to the acceptable efficiencies discussed above, the model results are compared to published results of other models for historical data (e.g. Kranzl et al. 2010; Pöhler et al. 2010; Stanzel and Nachtnebel 2010; Klein et al. 2011; Kling et al. 2011; ZAMG/TU-Wien Studie 2011). As an example, the model performance to simulate observed runoff for the two gauging stations PassauIngling $\left(26,084 \mathrm{~km}^{2}\right)$ and Golling $\left(3555.7 \mathrm{~km}^{2}\right)$ at the Rivers Inn and Salzach, respectively, is shown in Fig. 4 compared to the simulations by Pöhler et al. (2010), which used the physically based model WaSiM-ETH at a daily time step. A general agreement between observed data, the published simulated data from the distributed model WaSiM-ETH (reduced to a monthly time step), and the simulations from the parsimonious lumped-parameter model used herein $(\mathrm{GR} 2 \mathrm{M}+)$ increases the confidence in the appropriateness of the simple model structure to generate monthly runoff data. In addition, the benchmark approach described in Schaefli and Gupta (2007) based on interannual mean monthly runoff values yields NSE values of 0.681 for Passau-Ingling and 0.808 for Golling. Actual 


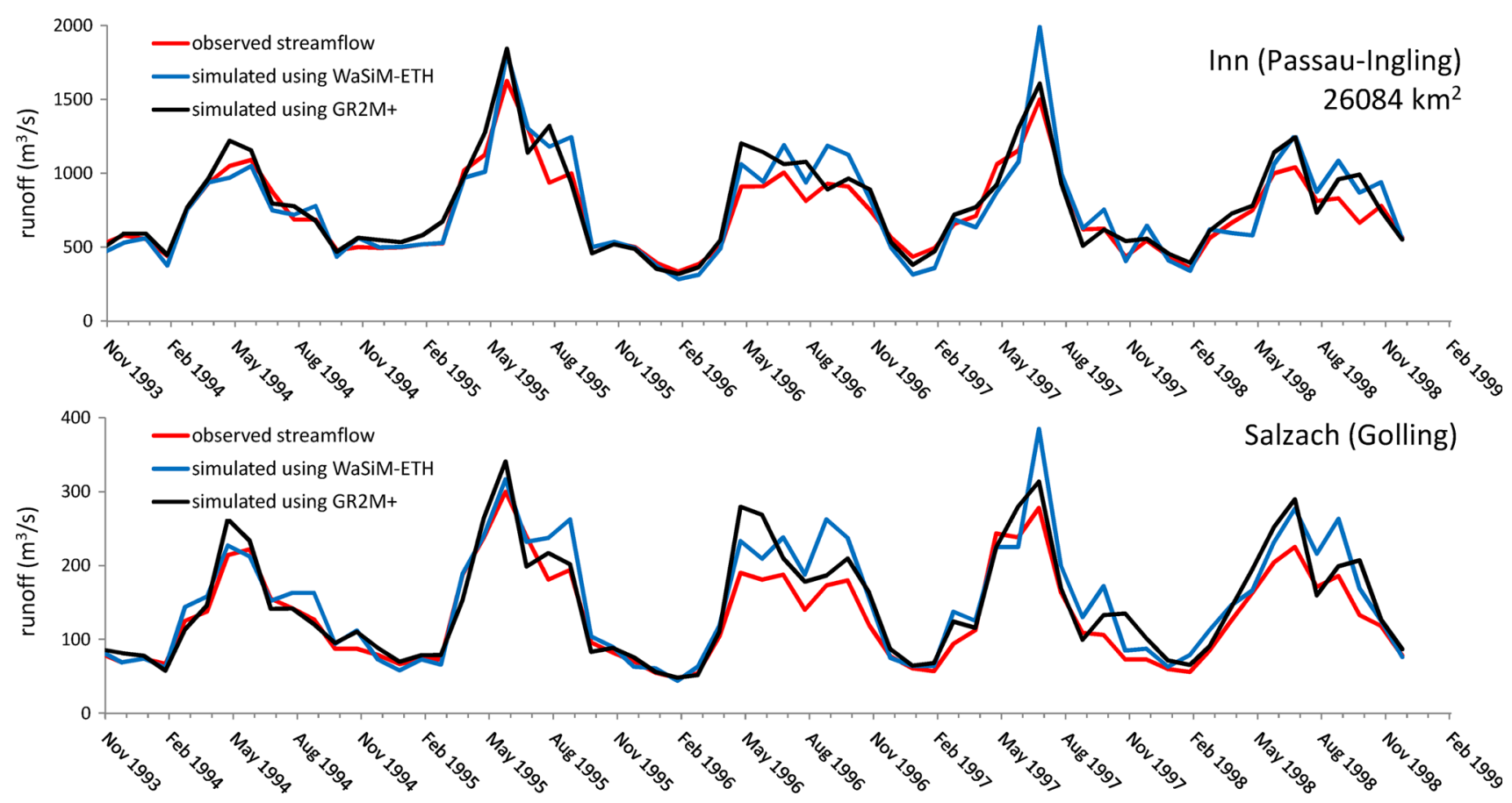

Fig. 4 Observed and simulated monthly runoff data for the two Austrian gauging stations Passau-Ingling (Inn River) and Golling (Salzach River). Red lines are the observed hydrographs; blue lines are the simulated data using the physically based catchment model

NSE values for the runoff simulation of the GR2M+ for the two gauging stations are higher (0.874 and 0.848). On the one hand, this demonstrates an expected strong seasonality of the runoff and, on the other hand, that the model is superior to a simple interannual monthly mean.

\section{Hydro power model for run-of-river plants}

The direct impacts of long-term average climate changes can be estimated by investigating changes in the average annual electricity generation of run-of-river plants, which is defined in this paper as the long-term average annual net electrical energy output of every single plant within the model. To convert the simulated river runoffs to the energy output of run-of-river plants, conversion models (e.g. Kishor et al. 2007; Acakpovi et al. 2014) were used. For the hydro power plants, the corresponding runoff gauging station was assigned by using the nearest station along the river. The relationship between the changes in runoff and the changes in the average annual electricity generation of run-of-river plants depends on technical parameters of the individual hydro power plant as well as on possible differences in size of the catchment areas of the gauging station and the hydro power plant.

For the hydro power plants in Austria, the known technical parameters, such as hydraulic head, maximum inflow, and maximum capacity, as well as historical runoff
WaSiM-ETH as reported in and digitized from Pöhler et al. (2010) and the black lines are the simulated runoffs using the parsimonious lumped-parameter model used in this work (GR2M+)

data are used as model input to calculate hydro power generation on a daily basis for each power plant (Schüppel 2010). The model then is calibrated to the historical power generation data by adjusting the unknown efficiency factor of the power plant, assuming as an approximation that the known average head height is constant.

$W_{\mathrm{el}, \mathrm{d}}=Q_{\mathrm{PP}, \mathrm{d}} \cdot \bar{H} \cdot g \cdot \rho \cdot \eta_{\mathrm{el}}$

where $W_{\mathrm{el}, d}(\mathrm{Ws})$ is the daily electrical energy produced by the power plant at day d, $Q_{\mathrm{PP}, \mathrm{d}}\left(\mathrm{m}^{3}\right)$ is the water volume flowing into the power plant at day $\mathrm{d}$ (see below), $\bar{H}(\mathrm{~m})$ is the average hydraulic head, $g\left(\mathrm{~m} / \mathrm{s}^{2}\right)$ is the gravitational acceleration. $\rho\left(\mathrm{kg} / \mathrm{m}^{3}\right)$ is the density of water and $\eta_{\mathrm{el}}(-)$ is the total efficiency of the power plant, used to calibrate the model.

Another variable factor accounting for the aforementioned difference between the catchment areas of the stream gauge and the power plant is calibrated using the average annual electricity generation.

$Q_{\mathrm{PP}, \mathrm{d}}= \begin{cases}Q_{\max } & f \cdot Q_{\mathrm{mod}, d}>Q_{\max } \\ f \cdot Q_{\mathrm{mod}, \mathrm{d}} & 0 \leq f \cdot Q_{\mathrm{mod}, \mathrm{d}}<Q_{\max }\end{cases}$

where $Q_{\text {mod }}\left(\mathrm{m}^{3}\right)$ is the historical runoff volume for day d, modified by the results of the hydrological model output, $Q_{\max }\left(\mathrm{m}^{3}\right)$ is the maximum daily inflow capacity of the power plant, and $f(-)$ is the catchment size correction factor, ratio of model catchment size and plant catchment size. 
Based on the monthly simulation results from the hydrological model, changes in the monthly flow duration curves of the nearest gauging stations are computed and used to alter the monthly duration curves from the hydro power plants (derived from historical daily inflow data, delta-sigma approach). Changes in the characteristics (e.g. increasing frequency of high water) are approximated by altering the historical inflow data considering the simulated changes in the standard deviations in the monthly runoff data simulated by the hydrological model. The modified flow duration curves are then fed into the power plant model. Although this is a simple approach of converting monthly to daily inflow data, it is considered a reasonable first approximation. More complex stream flow conversions exist (e.g. Rebora et al. 2016), but are beyond the scope of this paper. The resulting changes in average annual electricity generation and monthly generation coefficients (monthly share of the annual energy yield) are the final results discussed here (and can be used for further economic considerations, as was done within the EL.ADAPT project: Bachner et al. 2013).

Due to a lack of technical information and temporal resolution of runoff data on individual hydro power plants, a less detailed linear approach was used for the hydro power plants in other countries (Italy, Switzerland, Germany, and France), mapping the monthly change signals of runoff directly to the monthly average amounts of electricity generation and neglecting the nonlinear effects of changing runoff characteristics and the limiting inflow capacity (delta approach).

$W_{\mathrm{el}, \mathrm{m}}^{\mathrm{CC}}=W_{\mathrm{el}, \mathrm{m}}^{\mathrm{hist}} \cdot\left(1+\Delta q_{\%}\right)$

where $W_{\mathrm{el}, \mathrm{m}}^{\mathrm{CC}}(\mathrm{Ws})$ is the monthly average electricity generation in the future affected by climate change, $W_{\mathrm{el}, \mathrm{m}}^{\mathrm{hist}}(\mathrm{Ws})$ is the historical monthly average generation, and $\Delta q_{\%}$ is the relative change in monthly runoff of the corresponding gauge (climate change signal).

Calibration of the individual hydro power stations in Austria results in efficiencies on average of 0.83 (with a standard deviation of 0.12; see Eq. (1) and Bachner et al. 2013, p. 92-94 for details). These values are within a reasonable range (e.g. Giesecke et al. 2014, p. 32). Due to the lack of technical data, efficiencies were not calculated for the stations outside Austria.

At the end of their operational period, hydro power plants will be renewed (refurbished). These refurbishments are assumed to result in an increasing capacity (rated power) by $5 \%$ and are correspondingly considered in the average annual electricity generations modified by the hydrological model results. Moreover, an increase in the number of hydro power plants is expected in the future. This increase has been estimated based on various sources, e.g. World Energy Outlook 2010 and the National Renewable Energy Action Plans of EU member states (see Bachner et al. 2013 for more details), and is considered by incorporating additional hydro power plants in the model for the future periods. Yet within this paper, all results are referred to a base scenario that includes the same changes (including additional generation capacities) in the hydro power generation system such that the estimated change in electricity production only results from the hydrological change.

\section{Results}

In this section, the various results from the individual elements of the model chain and effects related to the subsequent elements are addressed. Potential uncertainties of the individual model steps and their further consequences are discussed in the subsequent section.

\section{Changes in meteorological forcing (temperature and precipitation)}

Regarding meteorological forcing, four representative regional climate scenarios have been selected to cover a large uncertainty range of expected climate change. The selected RCMs show different characteristics: Meteo-HC HadRM3Q0 being a hot and dry realization, C4IRCA3 being a warm and wet realization, KNMI-RACMO2 being a moderate realization, and CNRM-RM4.5 representing a special case, which shows stronger summer than winter warming. The climate change signals for all the considered 101 catchments between 1961-1990 and 2011-2030 and between 1961-1990 and 2031-2050 of the selected RCMs are summarized in Fig. 5 in a cumulative frequency plot. For the individual catchments of the gauging stations Kienstock $\left(95,970 \mathrm{~km}^{2}\right)$ and Passau-Ingling $\left(26,084 \mathrm{~km}^{2}\right)$ along the rivers Danube and Inn (which will be used as examples in detail also in the next sections), a change in temperature from +0.7 to $+2.5^{\circ} \mathrm{C}$ and from +0.7 to $+2.7^{\circ} \mathrm{C}$, respectively, and in precipitation from $+5 \mathrm{~mm} /$ year to $+106 \mathrm{~mm} /$ year and from $-11 \mathrm{~mm} /$ year to $+111 \mathrm{~mm} /$ year, respectively, is estimated (Fig. 5; the triangles and crosses, respectively). The cumulative frequency plots of absolute temperature change and absolute precipitation change illustrate the differences in the climate scenarios. Although the trend in temperature change is consistently positive, the magnitudes are different and of importance concerning future changes in evapotranspiration. Interestingly, the cumulative frequency plots of the individual scenarios are rather steep, indicating a low variability of the projected temperature increase within the Alpine region. The picture of precipitation change is more 

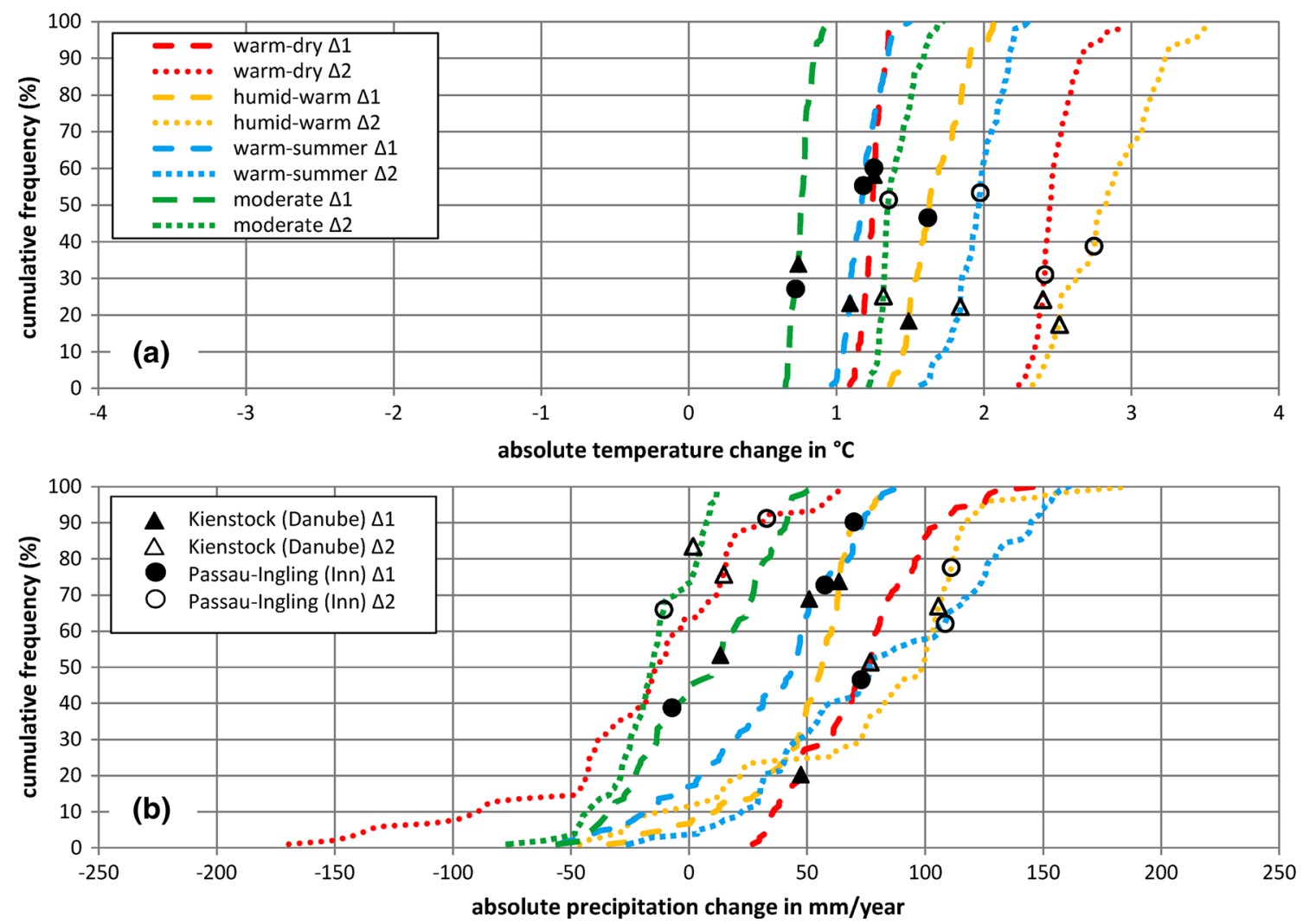

Fig. 5 Mean climate change signal for air temperature $\left({ }^{\circ} \mathrm{C}\right)$ and precipitation (mm/year) for the period 2011-2030 and 2031-2050 compared to 1961-1990 for all the 101 catchments considered in the analysis; individual results for the catchments of the gauging station Kienstock (Danube River) and for the catchment of the gauging

diverse, on the one hand regarding the differences between the individual scenarios, and on the other hand, regarding the variability within the Alpine region, as most scenarios display a range of positive as well as negative changes of more than $50 \mathrm{~mm} /$ year. This is reflecting the complex meteorological behaviour of the Alpine region.

\section{Estimated runoff changes based on four climate scenarios}

Using temperature and precipitation input from the four climate scenarios individually, the calibrated and validated hydrological model is used to simulate runoff for the two periods 2011-2030 and 2031-2050. The results are compared to the reference period 1961-1990 for all 101 catchments. As representative examples, three gauging stations related to a range of catchment sizes are shown in Fig. 6 (their locations are indicated in Fig. 1a). Figure 6a shows the predicted seasonal change in the mean monthly runoff of the River Danube at the station Kienstock for each of the four climate change scenarios. Figure $6 \mathrm{~b}, \mathrm{c}$ shows the same but for the station Passau-Ingling and Imst station Passau-Ingling (Inn River) are indicated for each of the climate scenarios and time periods as triangles and crosses, respectively. Closed symbols for 2011-2030 compared to 1961-1990, open symbols for 2031-2050 compared to 1961-1990. For the location of these gauging stations, see Fig. 1

of the river Inn. Subtracting the runoff simulated for the reference period 1961-1990 from the predicted mean monthly runoff of the respective time period yields the expected change in monthly runoff for each of the four climate scenarios (Fig. 6d-f). The overall annual changes for the two periods 2011-2030 and 2031-2050 related to the reference period 1961-1990 are shown on the very left of Fig. 6d-e. Note that small absolute increases in the runoff during periods of low flow (e.g. in winter) might yield large relative changes (up to $100 \%$ and more, e.g. Fig. 6f); however, these might not have a great influence on the difference in the overall annual runoff.

In general, especially for the smaller (and mostly mountainous) catchments considered, a shift towards earlier runoff (especially months of February to May) and a decrease in the summer months (July to August/September) are observable. Monthly variations up to $+190 \%$ are observed due to seasonal changes and a shift towards higher runoff especially in March and April related to a warming trend observed in all four scenarios. The strongest decrease of up to $-70 \%$ is observed in the summer months of July and August (most pronounced in the warm-dry 

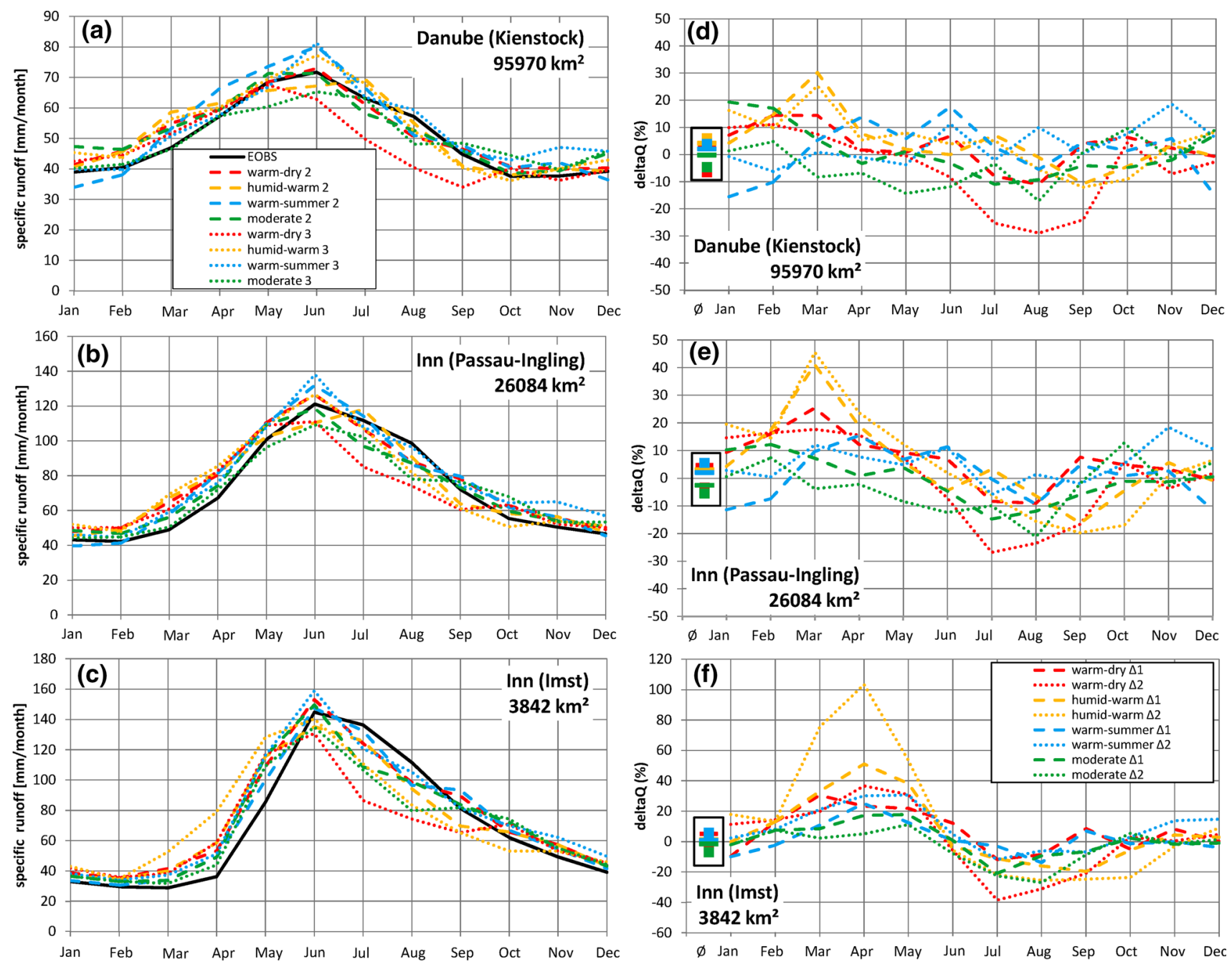

Fig. 6 Seasonal change in the mean monthly predicted runoff of the station Kienstock (Danube River) (a), the station Passau-Ingling (Inn River) (b) and the station Imst (Inn River) (c) relative to the historical runoff (simulated using the E-OBS data set). The observed runoff and the simulated runoffs for the period 1961-1990 using the historical time frame of the individual scenarios are not shown here as these are very similar to the simulated historical runoff of the E-OBS data set (due to the calibration process). The numbers 2 and 3 in the legend are

related to the time periods 2011-2030 and 2031-2050, respectively. d-f show the difference per month of the runoff for the two time periods 2011-2030 versus 1961-1990 ( $\Delta 1)$ and 2031-2050 versus 1961-1990 ( $\Delta 2)$ for the stations in $(\mathbf{a}-\mathbf{c})$, respectively. Within the black boxes on the left of (d-f), the mean annual runoff is depicted; bars for $\Delta 1$ and rectangles for $\Delta 2$. For the location of these gauging stations, see Fig. 1

scenario for the period 2031-2050 compared to 1961-1990). An example of both effects being observable is shown for the River Inn at the gauging station Imst in Fig. $6 c, f$.

In addition to the mean monthly runoffs $(\mu)$ as shown in Fig. 6, the standard deviations $(\sigma)$ of the runoff for each catchment, each month, and each scenario for both time periods 2011-2030 and 2031-2050 versus the reference period 1961-1990 were computed to get a bandwidth of possible runoff changes in the near future (as an example see Fig. 7). The monthly changes in runoff computed for the different climate scenarios were further used as input

for the hydro power model ("Changes in the hydro power generation" section).

Depending on the climate scenario used, there is a certain variation in the change in runoff for all the catchments analysed and moreover for the periods 2011-2030 and 2031-2050 compared to the reference period 1961-1990 (Fig. 8). Interestingly, in the warm-dry scenario, a positive trend in runoff change is observed for the period 2011-2030, whereas a strong decrease is estimated for the period 2031-2050. However, this is not unexpected, as the precipitation patterns already demonstrate such a behaviour (Fig. 5). Nevertheless, the consistently positive changes in 


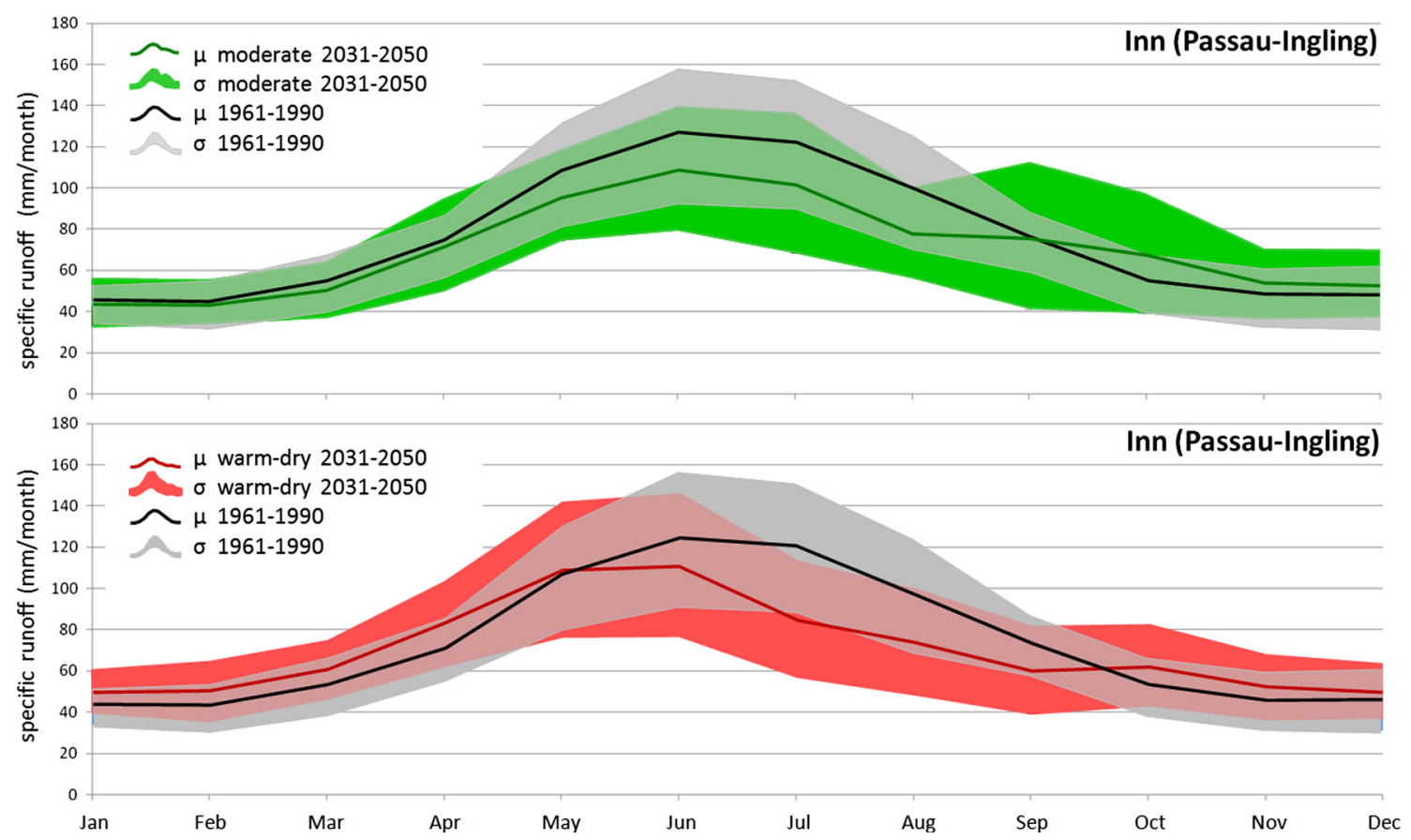

Fig. 7 Range of runoff (mean values $\mu$ and standard deviations $\sigma$ ) for the Inn River at the station Passau-Ingling $\left(26,084 \mathrm{~km}^{2}\right)$ for historical data (1961-1990) and the estimated ranges of future runoffs (2013-2050) for the moderate (top, green) and the warm-dry (bottom, red) scenarios

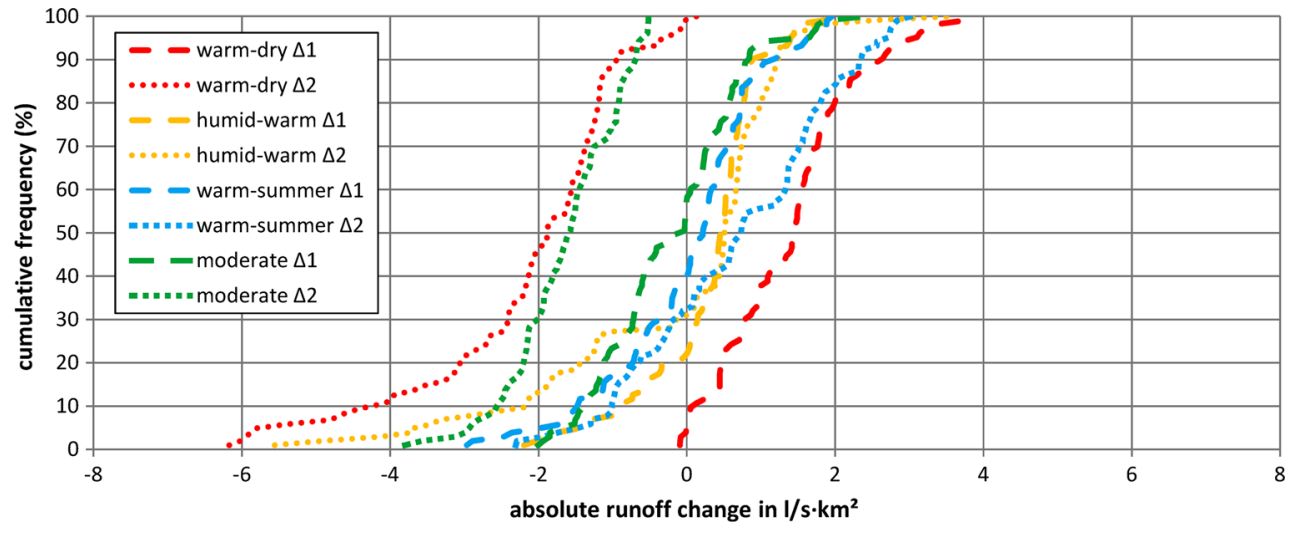

Fig. 8 Cumulative frequency of absolute runoff change (in $1 / \mathrm{s} \mathrm{km}^{2}$ ) for all the analysed catchments of the GAR. Red lines represent the changes in runoff for the warm-dry scenario, orange ones for the humid-warm scenario, blue ones for the warm-summer scenario, and

temperature (Fig. 5a) generally result in more negative changes in runoff (Fig. 8) compared to the changes in precipitation (Fig. 5b). The warm-dry as well as the moderate scenarios for the periods 2031-2050 suggest a consistent decrease in runoff for all the catchments analysed compared to 1961-1990. In contrast, only the warm-dry scenario for 2011-2030 results in a generally positive runoff change compared to 1961-1990. Interestingly, the cumulative frequency plots show clearly that the maximum and minimum changes result from the two time periods considered within a single scenario (the warm-dry one). green ones for the moderate scenario. Dashed lines relate to the difference in runoff for the time period 2011-2030 versus 1961-1990 $(\Delta 1)$ and the dotted lines to the period 2031-2050 versus 1961-1990 $(\Delta 2)$

As Fig. 8 allows no spatial differentiation between individual regions, Fig. 9a-h shows the relative changes in the mean annual runoff of all catchments considered for the four scenarios and the two time periods. Besides the mentioned differences between individual scenarios as shown in Fig. 8, Fig. 9 reveals very diverse spatial distributions with rather inconsistent runoff changes. However, the south-western part of the study area, namely the Rhone River and its tributaries, exhibits a consistent negative trend for the period 2031-2050. The Rhine River (northwestern part), the Danube River (north-eastern part), and 
Fig. 9 Computed changes in runoff for the considered catchments of the GAR. Changes are in per cent $(\%)$ of 2011-2030 versus 1961-1990 (a-d) and 2031-2050 versus 1961-1990 (e-h) for the four climate scenarios (a, e warmdry scenario; $\mathbf{b}, \mathbf{f}$ humid-warm scenario; c, $\mathbf{g}$ warm-summer scenario; $\mathbf{d}, \mathbf{h}$ moderate scenario). The computed changes are related to the outlets of the actual catchments, but the colour-coding of smaller subcatchments is superposed on the corresponding larger catchments

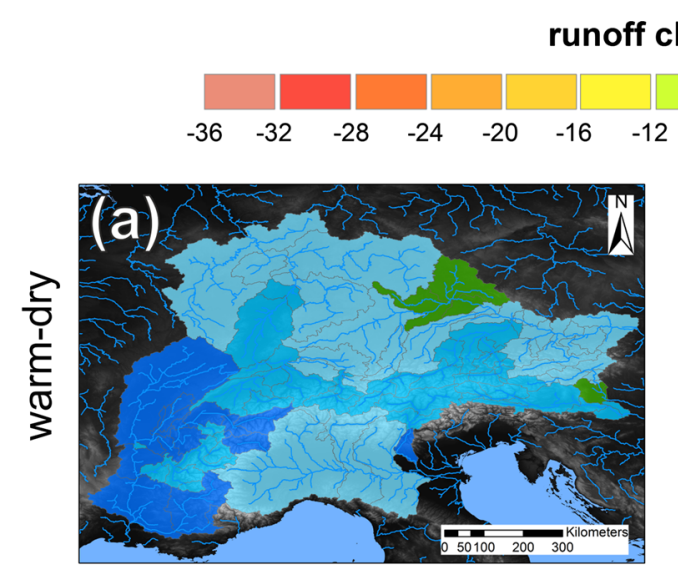

runoff change in $\%$
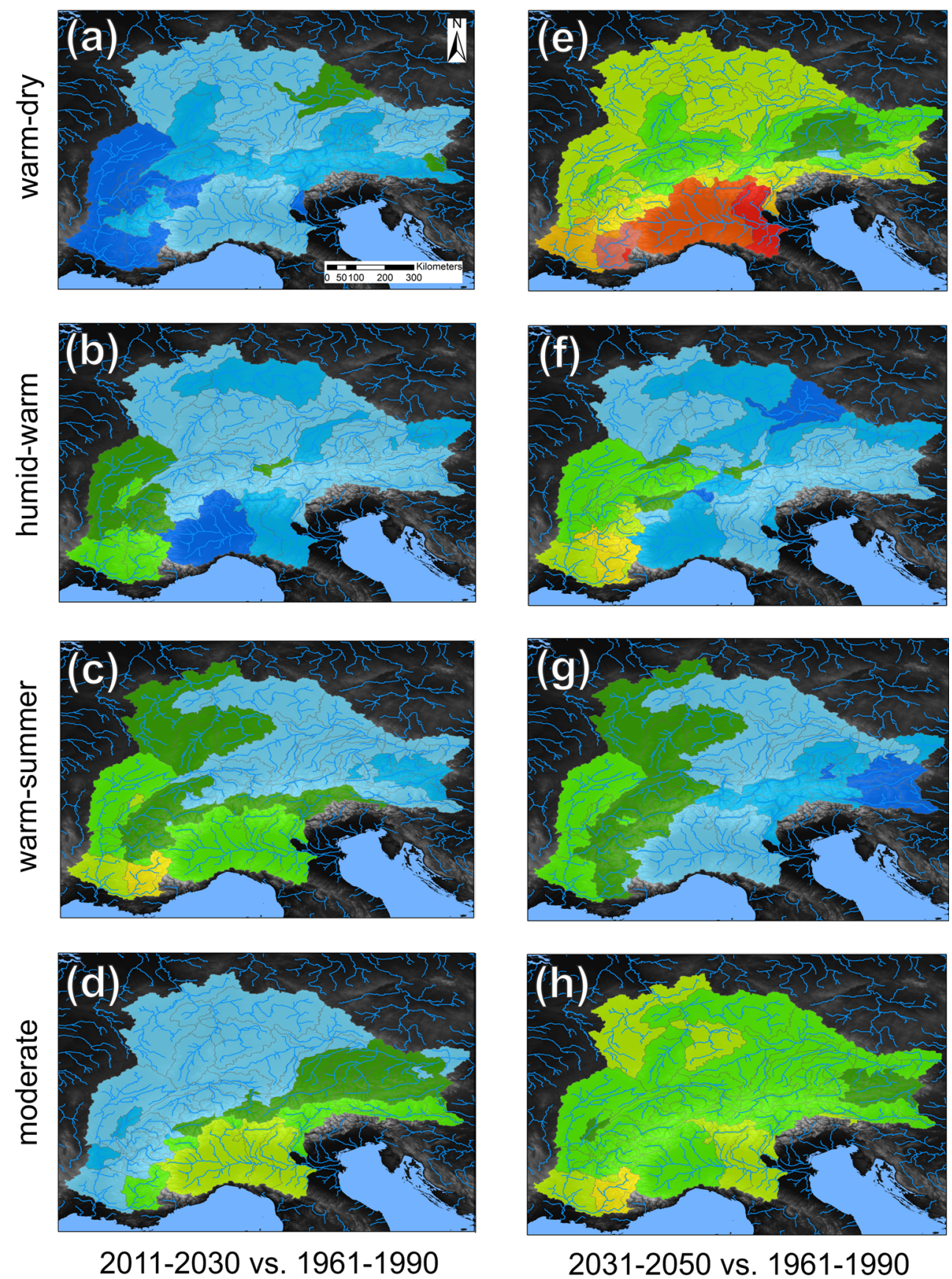

also the Po River (south-eastern part) and their respective tributaries do not show a consistent trend.

\section{Changes in the hydro power generation}

Since hydro power plants are not able to convert the total available river runoff into electricity due to discharge capacities, environmental measures, and power plant efficiencies, changes in runoff might have diverse effects on the actual power generation as will be discussed in the following. Figure 10 depicts an example of the influence of runoff changes for monthly hydro power production. On the one hand, the power plant generation capacity is limited to a certain amount of discharge due to cost-optimized 
operation, so that certain changes in stream flow at higher levels do not affect the energy output, because the additional water is passing the hydro power plant via a spillway. On the other hand, runoff shifts, e.g. to earlier months of the year (due to a general warming trend resulting in less snow storage and earlier snow melt), can lead to an increase in power output of the plant if these water volumes were previously lost via the spillway and can now be used to generate electrical energy. As noted in "Hydro power model for run-of-river plants" section, these effects were considered only for power plants in Austria due to the lack of data on the individual power plants in other parts of the Alpine region.

Within the project framework of this study (see Bachner et al. 2013), changes in power plant structures have been considered in the future, which does not allow a direct comparison of the future periods (2011-2030 and 2031-2050) with the historical period (1961-1990).
Consequently, a scenario neglecting climate change (i.e. using the unmodified historical flow duration curves for the future time periods), but considering the changes in the power plant structure, i.e. refurbishment or additional capacities, had to be computed. Thus, a comparison between the climate scenarios and this base case (here called "BASE" scenario) was made.

For the two time periods considered, relative changes in average annual electricity generation compared to the BASE scenario (without consideration of climate change) are shown for the entire GAR and for Austria in particular (Fig. 11a, b).

Considering all simulated run-of-river hydro power plants (390 in total), Fig. 11a, b shows that the projected climate change leads to an increase in total average annual electricity generation by $5 \%$ in the GAR in the most positive case (warm-dry scenario) for the time period 2011-2030 and to a decrease by 7\% in the most negative

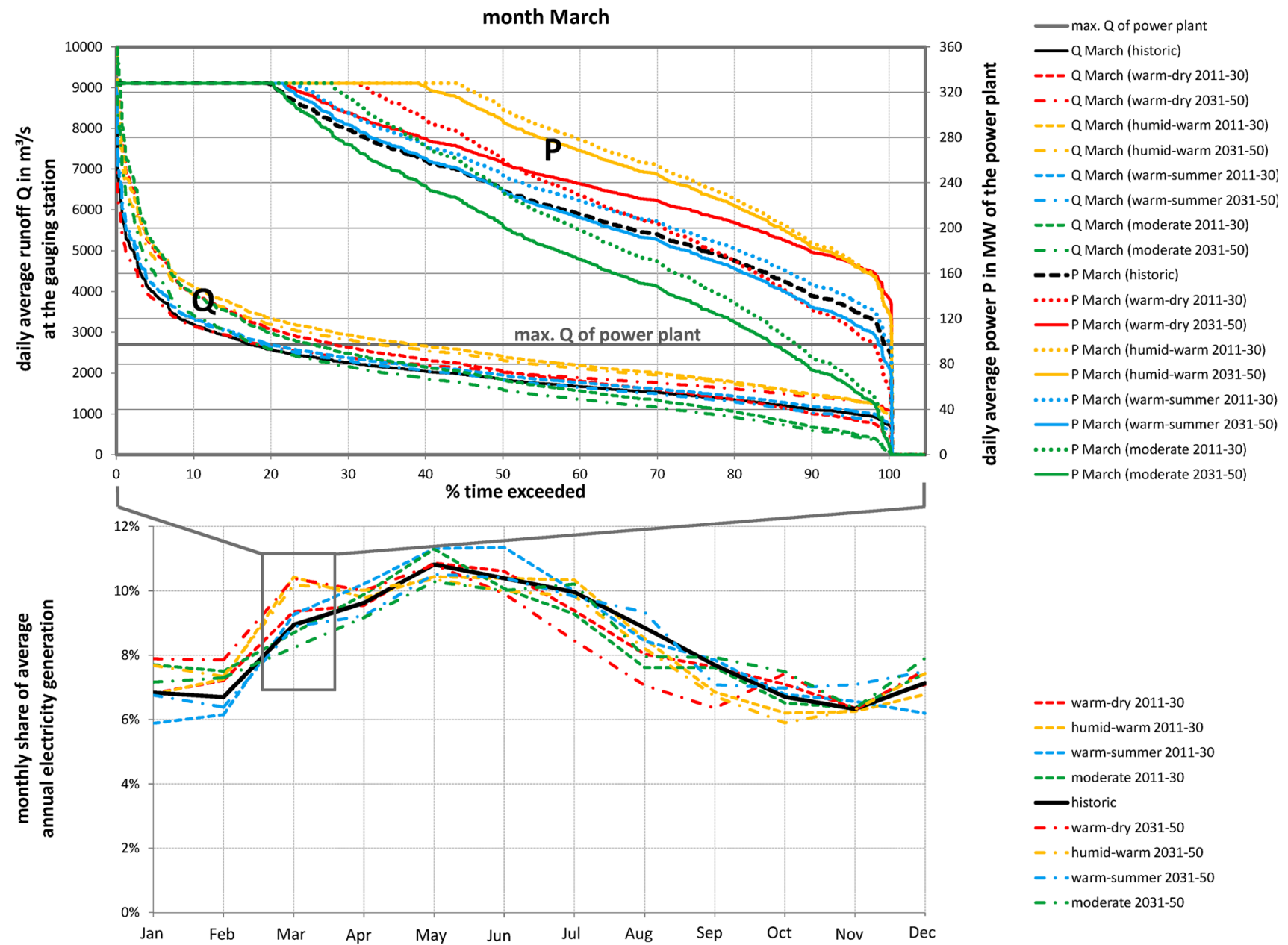

Fig. 10 Monthly share of average annual electricity generation (in $\%$ ) for the run-of-river plant Altenwörth at the Danube River for the historical time period and two future periods based on the four climate scenarios and computed runoff changes. Exemplarily, runoff changes $(Q)$ at the gauging station Kienstock at the Danube River and related changes in the power generation $(P)$ of the run-of-river plant Altenwörth for the month March are displayed in more detail. Note the maximum discharge capacity of the power plant (horizontal grey line) and consequently the maximum power production 


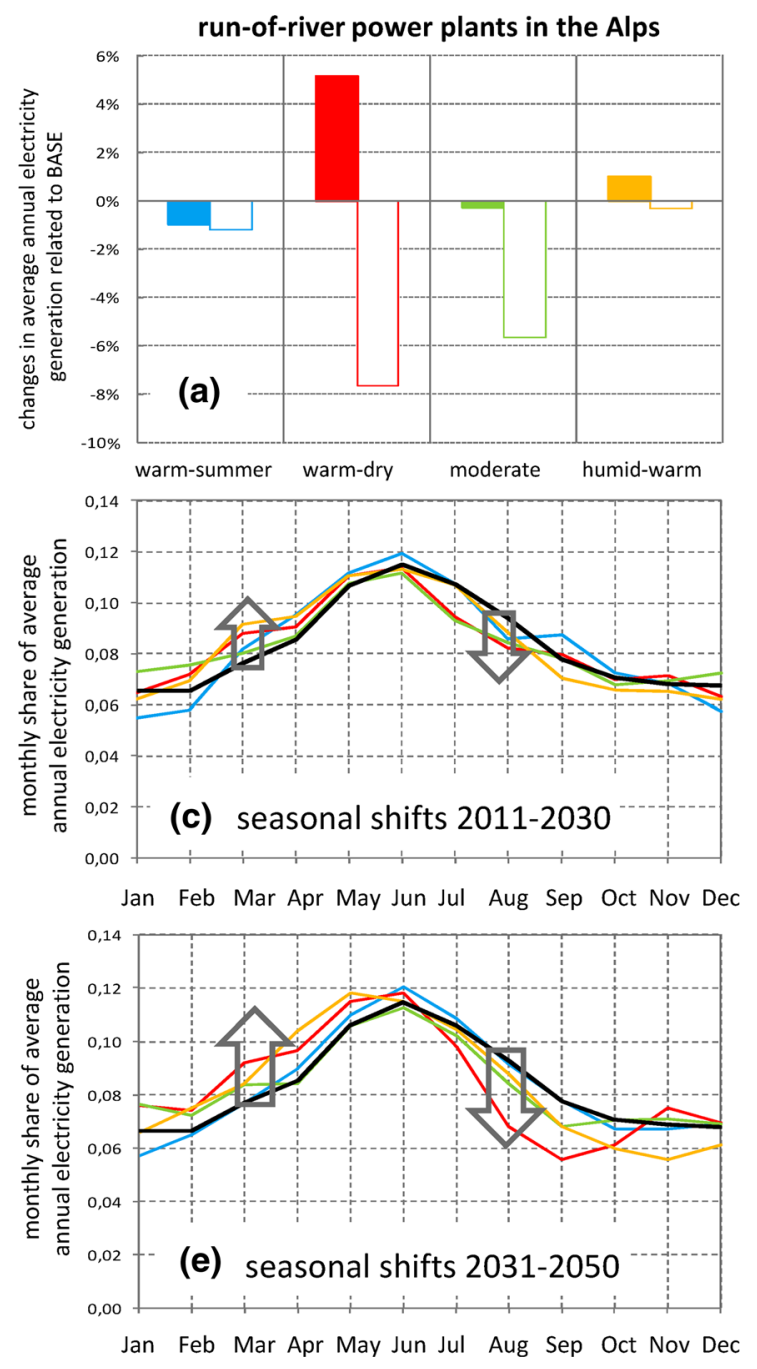

Fig. 11 Annual and seasonal changes in electricity generation for the Alpine region and Austria. Changes in average annual electricity generation for the Alpine region (a) and for Austria (b) for the periods 2011-2030 and 2031-2050 related to BASE. Seasonal characteristics of hydro power generation (monthly share of average annual

case (warm-dry scenario as well) for the time period 2031-2050. This is a progression of what was already indicated in the runoff data (see Fig. 8). The bandwidth of projected changes in Austria's average annual electricity generation is slightly lower compared to those of the GAR, ranging from an increase by almost $4 \%$ in the humid-warm scenario for the time period 2031-2050 to a decrease by about $4 \%$ in the moderate scenario for the same time period in the most negative case.

Besides the changing annual production, seasonal shifts are very important for the hydro power generation. Hydro power in Austria reaches its maximum production in spring, due to melting snow in the Alps, and its lowest energy output usually in February. However, due to a general warming trend, a seasonal shift is estimated in the future (Fig. 11c-f). run-of-river power plants in Austria

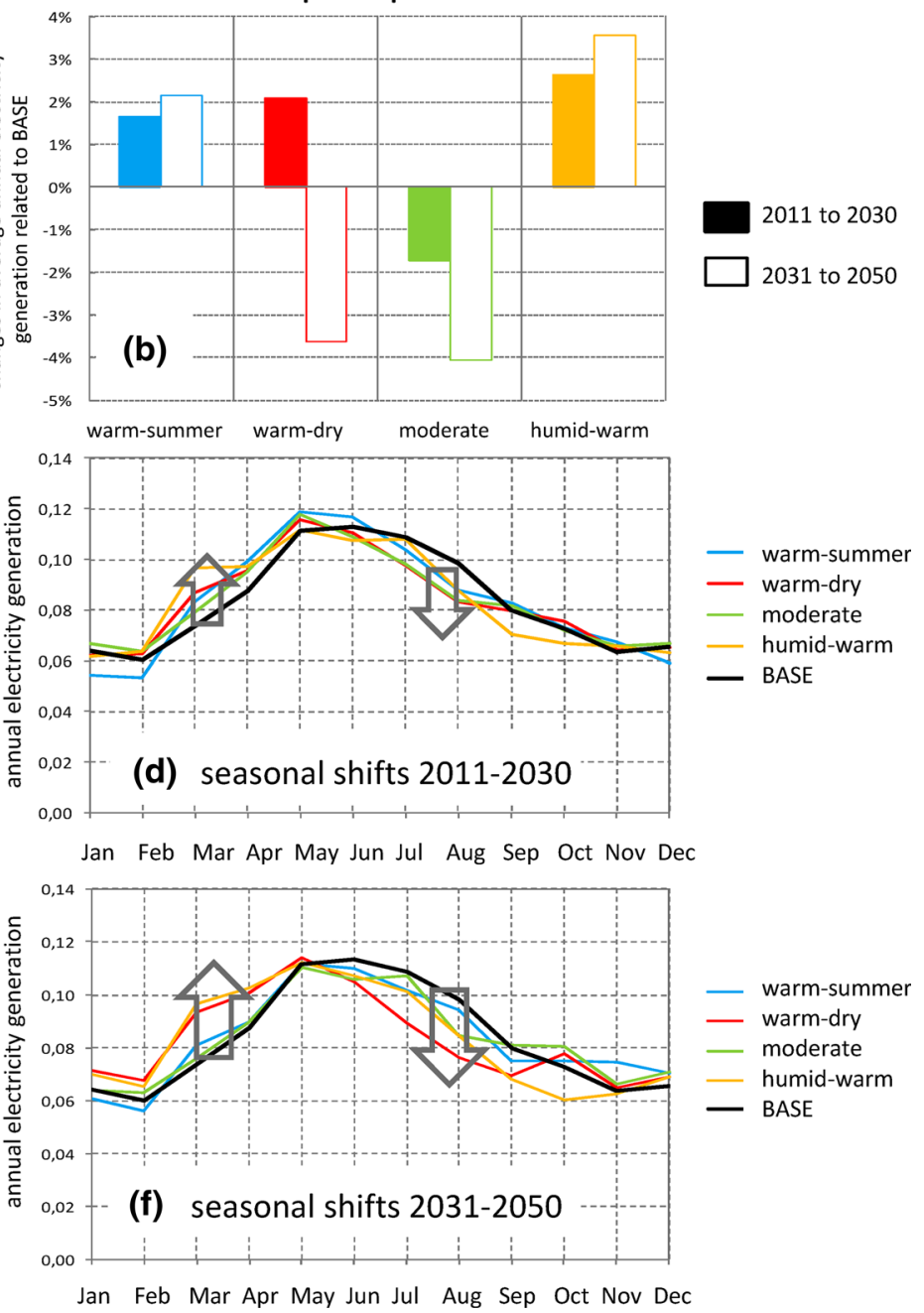

electricity generation) for the period 2011-2030 in the Alpine region (c) and in Austria (d) and the period 2013-2050 in the Alpine region (e) and in Austria (f). Grey arrows indicate noticeable seasonal changes in monthly runoff

Monthly generation characteristics reflect the seasonal changes in runoff characteristics (see, e.g. Fig. 6): A shift towards the winter and spring (particularly, February to May) and a decrease in the summer months (particularly, July to August) are observed for all climate scenarios in Austria and for all except the warm-summer scenario in the GAR (where the decrease in summer months is not observed). The observed trends are noticeable already in the time period 2011-2030, but are more pronounced in 2030-2050.

The trends are similar in Austria and the GAR in general (Fig. 11c-f), pointing to an increased generation in winter and a decrease in summer. For the GAR having its peak load in winter, this is a positive development, because the additional energy yield supports and potentially stabilizes the energy system. 


\section{Discussion}

The resulting changes in energy production of run-ofriver plants due to changes in climate forcing and its consequences on river runoff and consequently on inflow for hydro power plants are related to a number of uncertainties along the model chain. The computed estimates of changes in runoff and further in energy production of run-of-river hydro power plants shown here are discussed in the light of these inherent uncertainties in the following.

To assess the uncertainty in the climatic input data, four different climate scenarios have been used to cover a wide range of possible future changes. These data sets cover a large part of climate uncertainty, but are based on only one emission scenario. However, for the period before 2050, it is expected that the effect of different emission scenarios on climate will be largely similar (Prein et al. 2011). Remarkable differences are expected in the second half of the twenty-first century only. All these four scenarios have been used as input for the hydrological model, but the historical runoff data, the model structure itself, and the model parameters contribute to the overall uncertainty, too. Runoff data from different data sources have been checked for outliers and plausibility. Nevertheless, measurement uncertainties are evident, especially for high and low flows. In fact, data quality is usually less of an issue for the monthly data, which is used for the monthly rainfall-runoff model, than for daily data (e.g. Smakhtin 2000); however, the lack of daily runoff subsequently introduces uncertainty in the compilation of future monthly flow duration curves (see below).

Figure 12 shows the absolute changes in temperature (a), the relative changes in precipitation (b), the relative changes in runoff (c), and the relative changes in hydro power production (d) resulting from the applied model chain. Thus, the figure compares the range of changes in the forcing parameters temperature and precipitation (Fig. 12a, b) with the resulting impact on runoff (Fig. 12c) and hydro power production of run-of-river plants (Fig. 12d). The large number of catchments and hydro power plants analysed allows observing a certain general progression from forcing input parameters to output parameters (i.e. runoff and hydro power production) in the Alpine region despite the uncertainties associated with the individual catchments or hydro power plants. The similarity in Fig. 12b-d suggests that changes in runoff and hydro power production are mainly controlled by the projected changes in precipitation. However, a closer look reveals that other factors contribute, too.

In particular, the expected increase in temperature generally leads to a decrease in runoff due to increased evapotranspiration and thus the relative changes in runoff are shifted to lower values as compared to the changes in precipitation. For instance, for the time period 2031-2050, the warm-dry scenario suggests an increase in precipitation of nearly $40 \%$ of the catchments, but this does not lead to an increased runoff in any of these catchments. For the same time period, the moderate scenario shows a similar average change in precipitation (with less variability throughout the GAR), but because of a lower increase in temperature the resulting change in runoff is less negative than that of the warm-dry scenario. Similarly, both the humid-warm and the warm-summer scenarios show an increase in precipitation from the time period 2011-2030 to the time period 2031-2050, but this difference is much less pronounced in the runoff changes because the temperature is expected to increase too, i.e. the projected increase in precipitation is almost compensated by the projected increase in temperature (and consequently in evapotranspiration).

The projected increase in evapotranspiration and thus decrease in runoff due to increasing air temperatures intuitively appear to be plausible. There are, however, multiple indications that this effect might be less strong than suggested by purely temperature-based evapotranspiration models as employed here and in other climate impact studies. First, it has been shown that despite global warming, the evaporative demand of the atmosphere globally exhibits little change (Sheffield et al. 2012) or may have even declined (McVicar et al. 2012) over the recent decades; this is attributed to changes in climate variables that are neglected in the temperature-based models, particularly wind speed (McVicar et al. 2012). Second, it is known that an increase in the $\mathrm{CO}_{2}$ concentration of the air, as observed during the recent and expected for the upcoming decades, causes plant stomata to open less widely, thus reducing the transpiration per leaf area (Lockwood 1999); evidence from experimental plots (e.g. Ainsworth and Long 2005) as well as from the analysis of continental runoff data (Betts et al. 2007) suggests that this effect is not generally compensated by an enhanced plant growth.

Although these considerations generally point to a potential overestimation of evapotranspiration and underestimation of runoff in the present study, it is evident that further investigations are needed to assess whether and how these findings can be transferred to the Alpine region and to the individual catchments investigated here. For example, the results shown by Sheffield et al. (2012) suggest that contrary to most other regions, the estimated increase in potential evaporation obtained from a temperature-based method might be too low rather than too high for large parts of Europe. 


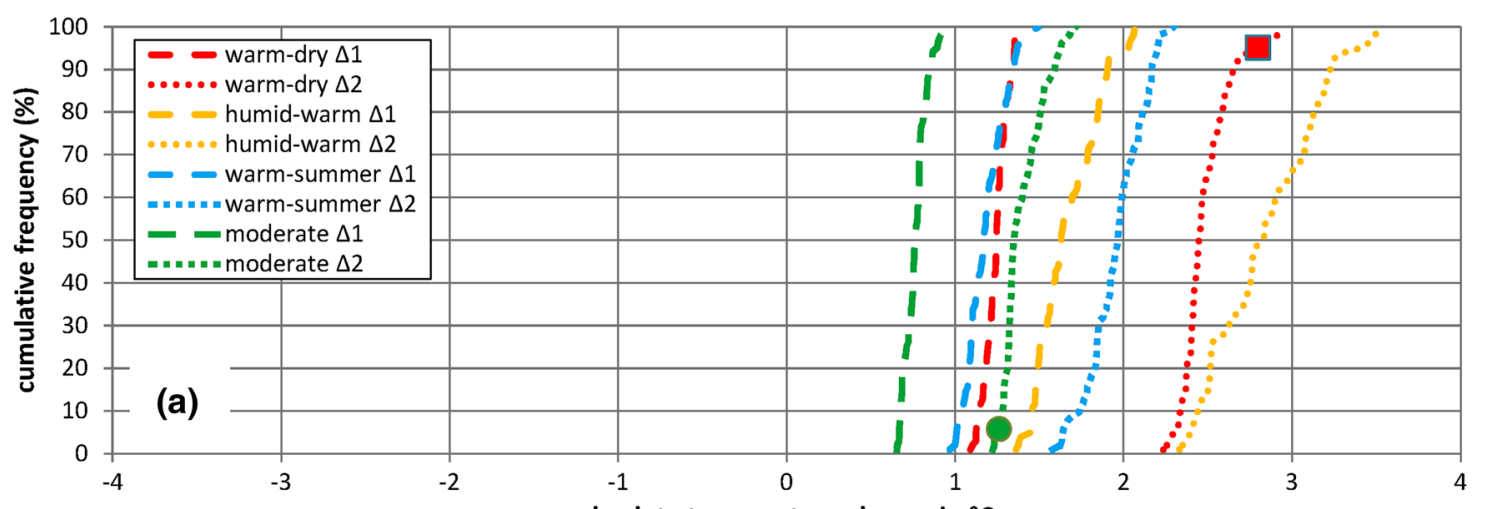

absolute temperature change in ${ }^{\circ} \mathrm{C}$

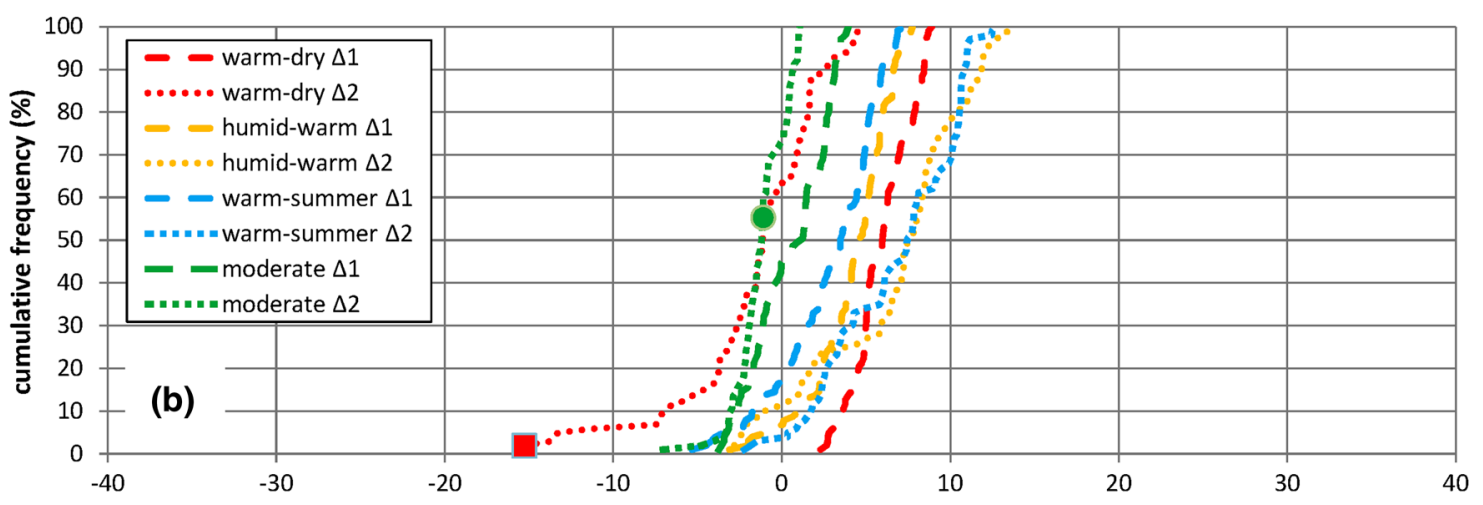

relative precipitation change in $\%$
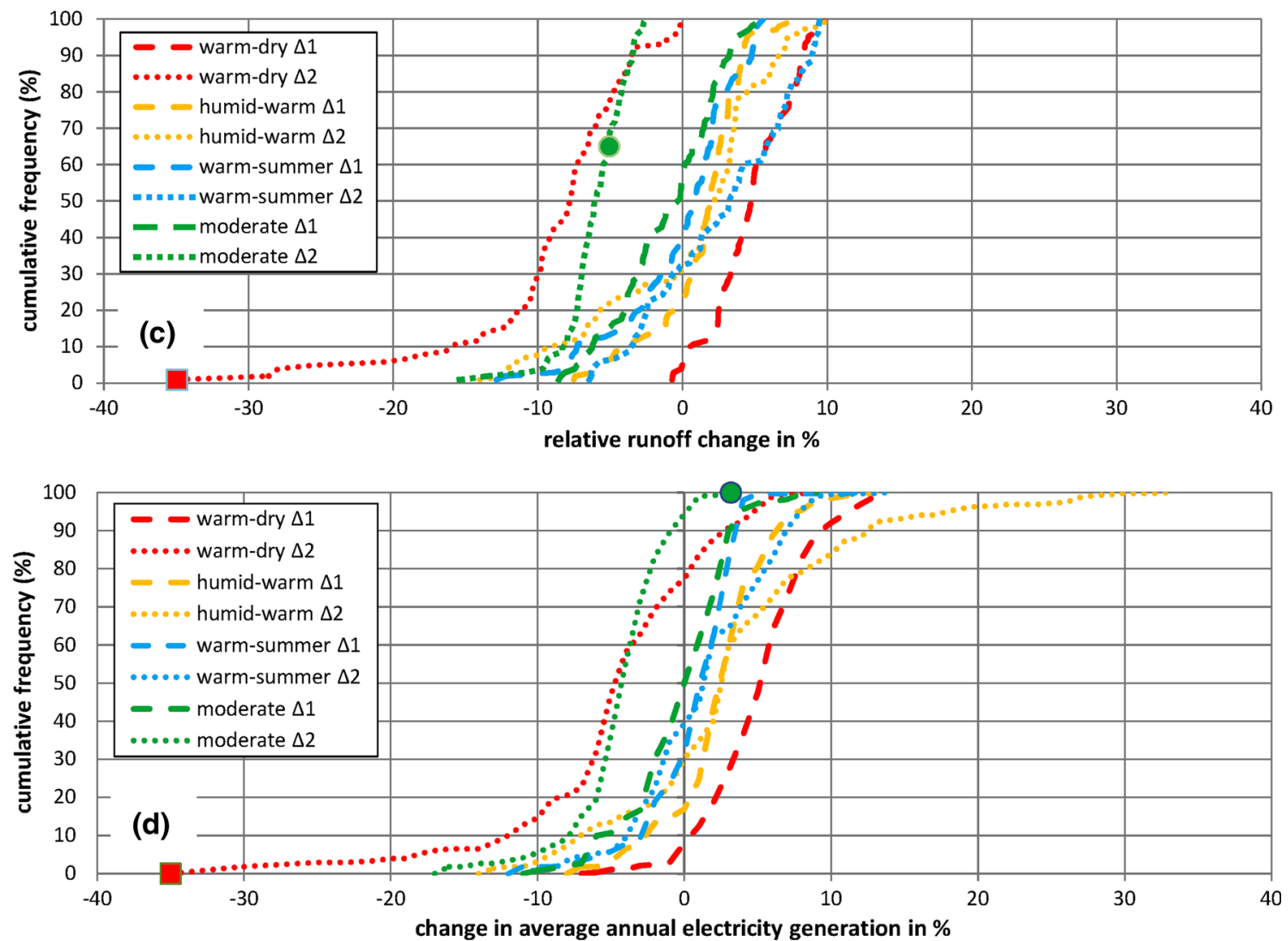
4Fig. 12 Absolute change in temperature (a), and relative changes in precipitation (b), in specific runoff (c) and in hydro power output (change in average annual electricity generation) (d) for the four climate scenarios and the time periods 2011-2030 and 2031-2050 versus 1961-1990 ( $\Delta 1$ and $\Delta 2$, respectively). The green circles exemplify the model chain for the change in temperature and precipitation in the time period 2031-2050 in the moderate scenario and its consequences on runoff at the gauging station Siezenheim (Saalach River) and the change in average annual electricity generation at the run-of-river plant Rott. The red boxes show the consequences of a change in temperature and precipitation in the time period 2031-2050 in the warm-dry scenario on runoff at the gauging station Saint Paul les Durances (Durance River) and the change in average annual electricity generation at the run-of-river plant La Brillanne

Future changes in soil properties, land use, and vegetation cover may also influence the transformation of precipitation to runoff, but as these changes are hardly predictable at the scale of this investigation, it was not attempted to account for them in the modelling. Likewise, an explicit modelling of glaciers has been refrained, due to the limited data availability (e.g. lack of a consistent glacier inventory for the Alpine region) and the difficulty of assessing possible temperature-related changes with the coarse available climate data set to our disposal. Fischer et al. (2015) estimated glacier runoff of approximately $600 \mathrm{~mm} /$ year $(-0.62 \mathrm{~m}$ water equivalent per year of glacier mass change) based on 30 years of historical data (1980-2010) in the Swiss Alps. This is about the same order of magnitude as the specific runoff (i.e. runoff per area) of the catchments considered here; thus, the actual percentage in runoff from glacier melt might roughly correspond to the areal percentage of glaciers within the catchment considered (see, e.g. Huss 2011 for further considerations). As such, runoffs in smaller alpine catchments with a large fraction of glaciers are influenced more than runoffs in foreland catchments. The larger run-of-river hydro power plants are situated along larger rivers of the Alps where catchment areas have a low fraction of glacier area (e.g. 1.4\% for the gauging station Passau-Ingling at the Inn River).

Due to increasing temperatures in the future and therefore ongoing glacier melt, related increases in runoff from glaciers will potentially be beneficial for hydro power production as glacier runoff contribution is expected to be important in the summer months where the predictions of the rainfall-runoff model GR2M+ suggest decreases. Huss (2011) could show a contribution of glacier-derived runoff in downstream basins of up to $25 \%$ in summer months; however, they noted a decrease in the far future (2100) due to strongly reduced glacier volumes. Predicting when the increase in glacier runoff due to increase in glacier melt is replaced by a decrease in runoff due to the disappearance of glaciers is an ongoing focus of research. For the time periods considered here (up to 2050), a slight increase (or decrease) in runoff due to additional glacier runoff (or the lack thereof) is likely (Huss 2011; Huss and Hock 2015); however, glacier runoff changes have been part of the historical time period as well and are as such indirectly addressed by the model calibration.

The employed hydrological model also does not explicitly take into account artificial structures like reservoirs or dams. Water losses as a result of human abstractions can make up a significant amount of the water supply. Especially in Mediterranean basins, abstractions and losses are altering the runoff quantity and runoff regime and will do so even more in the future if periods of droughts are increasing. The model implicitly allows accounting for water losses (using the exchange term $\mathrm{X}_{5}$ ); however, this works only if there is no considerable seasonal variation, as the parameter is constant over time. An increase in abstractions will lead to additional runoff reduction and consequently less hydro power production especially in the summer months.

Thus, in general, stationarity of model parameters is a questionable assumption and discussed in the literature (e.g. Milly et al. 2008; Vaze et al. 2010). However, for the purpose of this first Alpine wide assessment of potential consequences of climate change on hydro power production, the stationarity of parameters in the hydrological and hydro power models is a first assumption and an important step towards a better understanding of climate change impacts at the regional scale. Although incorporating additional processes or non-stationary parameters into the hydrological model is appealing, it bears the risk that the model is overparameterized (Loague and Freeze 1985; Beven 1989; Perrin et al. 2003). Only if additional data (e.g. groundwater levels) are available, more parameters are justifiable. Further research on these issues is desirable and the data quantity necessary for such investigations is certainly a challenge in itself.

To assess the parameter uncertainty in the given model structure, various parameter sets that lead to a similar acceptable fit (a "sufficiently accurate" simulation) of the historical data (principle of equifinality; Beven 1993) were used to compute runoff changes for the future (not shown here; for details, see Bachner et al. 2013, p. 59-68). Different "equally like" parameter sets due to equally acceptable fits to observed historical runoff data might lead to different future runoffs for the individual climate scenarios. The resulting range of possible runoff estimates is found to be small compared to the differences due to the different climate scenarios. Moreover, as there is a single hydrological model applied and as such only a single model structure used, some results were compared to published data to affirm its applicability (e.g. see Fig. 4; Bachner et al. 2013, p. 66). Overall, the simple model structure is found to be sufficient to cover 
changes in runoff estimates for future climate scenarios on a monthly basis.

As compared to the projected changes in runoff, the resulting changes in hydro power production are generally similar but tend to be slightly shifted to higher values (Fig. 12c, d). The most pronounced shift to higher values is observed for the upper part of the cumulative frequency distributions of both the humid-warm and the warm-dry scenarios in the time period 2031-2050. Despite the negative change in runoff generally projected for the warm-dry scenario, the average annual electricity generation is found to increase for approximately $20 \%$ of the hydro power plants. In the case of the humid-warm scenario, the maximum increase in hydro power production exceeds $30 \%$, although the maximum increase in runoff is less than $10 \%$. This illustrates the aforementioned positive effect of the projected seasonal changes in runoff on hydro power generation as exemplified by the green circles in Fig. 12, which refer to the moderate scenario (period 2031-2050) and the change in runoff at the gauging station Siezenheim along the River Saalach and the resulting change in the hydro power production of the run-of-river plant Rott. In this example, the decrease of $5.1 \%$ in annual runoff, resulting from an increase in temperature of $1.3{ }^{\circ} \mathrm{C}$ and a precipitation decrease of $1.1 \%$, leads to an increase in average annual electricity generation of $3.2 \%$. However, in case of a sharply decreasing runoff due to temperature increases and precipitation decreases affecting the whole year, a decrease in hydro power production is the obvious consequence. The red boxes in Fig. 12 provide an example where the temperature increase combined with strongly reduced precipitation causes a steep decline of runoff and hydro power production (warm-dry scenario; runoff at the gauging station Saint Paul les Durances (Durance River); hydro power production of the run-of-river plant La Brillanne). This negative trend in the south-western part of the Alpine region has already been mentioned in Fig. 9 for the runoff.

As demonstrated by the aforementioned example of runof-river plant Rott (green circles in Fig. 12), flow duration curves on daily data are desirable for the hydro power plants model. However, as only the monthly runoff is available from the hydrological modelling, the available historical flow duration curves for the Austrian power plants have been modified by a shift corresponding to the projected change in the monthly mean runoff and reshaping the curve by considering changes in the (monthly) standard deviation (see "Hydro power model for run-of-river plants" section). This simplified approach introduces additional uncertainty into the flow duration curves. More importantly, it was not possible to apply this approach to the non-Austrian hydro power plants due to the lack of data, which is why the projected changes in monthly runoff have been directly transferred to changes in monthly electricity generation (see "Hydro power model for run-ofriver plants" section).
Further uncertainties in the computation of the average annual electricity generations arise due to the model structure of the power plant model. Even the detailed approach used for Austria's power plants is not able to cover all effects of hydro power generation, e.g. caused by optimized dispatch using artificial reservoirs and the optimized utilization of different turbines within a power plant to reach their optimum operation point. Uncertainties are even higher in the less detailed approach for all other countries, not taking into account the limits of inflow capacities. Additional data of these hydro power plants would be needed for further analysis where potential positive effects of seasonal changes (due to the limits of inflow capacities) could be analysed similar to what has been done for the Austrian hydro power plants.

The estimates of future runoff and the resulting changes in hydro power generation represent a possible bandwidth of changes that the electricity sector and especially hydro power generation companies have to deal with in the near future. Climate projections and the corresponding results from the hydrological and hydro power model do not show a clear trend throughout the investigated area and time frame, mainly because of diverse precipitation patterns in contrast to a general warming trend in all four climate scenarios. Besides these obvious differences and therefore uncertainties from the climate modelling, other limitations and assumptions that have been addressed above tend to increase the bandwidth of uncertainty. However, many sources of uncertainty relate to the individual catchments or hydro power plants and thus are expected to have minor impact on the overall picture at regional scale (Fig. 12).

Thus, despite these uncertainties and simplifications discussed above, the analysis of the model chain covering the whole Alpine region provides a first scheme-scale analysis of possible impacts of climate change on the hydro power production of run-of-river plants in the GAR. The results provide a range of possible future climate change impacts to be considered in the planning and management of hydro power generation within the GAR and are expected to encourage further research in the complex interplay of climate, hydrology, and hydro power production in the Alpine region.

\section{Summary and conclusions}

Estimated changes in runoff for a large number of catchments covering the Greater Alpine Region were computed using a parsimonious lumped-parameter rainfall-runoff model and a range of climate scenarios as forcing input, which are further transformed to changes in hydro power production. The hydrological model has been used for simulating future runoff using precipitation and 
temperature input from four selected climate scenarios that cover a bandwidth of possible climate change for the near future up to 2050. Changes in the seasonality and a shift towards earlier runoff are found in all four climate scenarios to some extend and are related to a general warming trend, though their magnitudes are different. These seasonal changes result in monthly variations in runoff, where a general increase in runoff for the winter and spring (February to May) and a decrease in the summer months (July to August) are observable for all scenarios in the period 2031-2050. However, changes in precipitation are diverse for different scenarios, and as such, a general trend in runoff for certain regions is not as obvious. There are both positive and negative changes estimated, which can be related to the bandwidth (or uncertainty) of the different climate scenarios applied. The estimated average annual variations in runoff are in general within $\pm 10 \%$, but up to $-30 \%$ for the warm-dry scenario in Southern France and Northern Italy.

The effects of the four climate scenarios on runoff for the individual catchments are further translated to an estimate of future hydro power generation taking into account every scenario separately. In general, the shift to increased runoff in the winter and spring months due to a general increase in temperature indicates a positive effect on the power production, but the overall change remains more uncertain due to the ambiguous precipitation patterns in the climate scenarios. The average annual electricity generation of run-of-river plants for the time period 2031-2050 compared to 1961-1990 for the whole Alpine region is estimated to decrease slightly for all climate scenarios considered (up to $-8 \%$ ). For Austria, the result is more diverse, as two scenarios result in a slight increase (not more than $+5 \%$ ), whereas the other two scenarios result in a slight decrease (not more than $-5 \%$ ). While the selected scenarios are not expected to cover the full range of uncertainty, this bandwidth provides a first estimate of what can be expected in the near future for hydro power planning and management in the Alpine region.

Acknowledgements Open access funding provided by University of Graz. This work received financial support from the Climate and Energy Fund and was carried out within the framework of the ACRP programme. We thank all providers of historical runoff data: "The Global Runoff Data Centre, 56,068 Koblenz, Germany"; "Via Donau-Österreichische Wasserstraßen Gesellschaft mbH"; Hydrographischer Dienst Steiermark; Amt der Kärntner Landesregierung; A08 Hydrographie; Amt der Oberösterreichischen Landesregierung, Direktion Umwelt und Wasserwirtschaft Abteilung Oberflächengewässerwirtschaft; Hydrographischer Dienst Salzburg, Fachabteilung Wasserwirtschaft; Amt der Tiroler Landesregierung, Sachgebiet Hydrographie und Hydrologie; Referat für Oberflächenhydrologie, Abt. BD3-Hydrologie und Geoinformation, Amt der Niederösterreichischen Landesregierung; Amt der Vorarlberger Landesregierung, Abteilung Wasserwirtschaft; eHYD (http://gis.lebens ministerium.at/ehyd); Banque Hydro http://hydro.eaufrance.fr/ [equipe d'assistance]; the Slovenian Environment Agency: http:// www.arso.si/vode/podatki/arhiv/hidroloski_arhiv.html. We acknowledge the very constructive suggestions by Bettina Schaefli and an anonymous reviewer that greatly imporved the paper.

Open Access This article is distributed under the terms of the Creative Commons Attribution 4.0 International License (http://crea tivecommons.org/licenses/by/4.0/), which permits unrestricted use, distribution, and reproduction in any medium, provided you give appropriate credit to the original author(s) and the source, provide a link to the Creative Commons license, and indicate if changes were made.

\section{References}

Acakpovi A, Hagan EB, Fifatin FX (2014) Review of hydropower plant models. Int J Comput Appl 108(18):33-38

Ainsworth EA, Long SP (2005) What have we learned from 15 years of free-air $\mathrm{CO}_{2}$ enrichment (FACE)? A meta-analytic review of the responses of photosynthesis, canopy properties and plant production to rising $\mathrm{CO}_{2}$. New Phytol 165(2):351-372

Auer I, Böhm R, Jurkovic A, Lipa W, Orlik A, Potzmann R, Schöner W, Ungersböck M, Matulla C, Briffa K, Jones P, Efthymiadis D, Brunetti M, Nanni T, Maugeri M, Mercalli L, Mestre O, Moisselin J, Begert M, Müller-Westermeier G, Kveton V, Bochnicek O, Stastny P, Lapin M, Szalai S, Szentimrey T, Cegnar T, Dolinar M, Gajic-Capka M, Zaninovic K, Majstorovic Z, Nieplova E (2007) HISTALP-historical instrumental climatological surface time series of the Greater Alpine Region. Int $\mathbf{J}$ Climatol 27(1):17-46. doi:10.1002/joc.1377

Bachner G, Bednar-Friedl B, Birk S, Feichtinger G, Gobiet A, Gutschi C, Heinrich G, Kulmer V, Leuprecht A, Prettenthaler F, Rogler N, Schinko T, Schüppel A, Stigler H, Themeß1 M, Töglhofer C, Wagner T (2013) Impacts of climate change and adaption in the electricity sector-the case of Austria in a continental european context. Scientific Report No. 51-2013, Graz, ISBN 978-3-9503112-8-0

Beniston M, Jungo P (2002) Shifts in the distributions of pressure, temperature and moisture and changes in the typical weather patterns in the Alpine region in response to the behavior of the North Atlantic Oscillation. Theor Appl Climatol 71(1-2):29-42. doi:10.1007/s704-002-8206-7

Betts RA, Boucher O, Collins M, Cox PM, Falloon PD, Gedney N, Hemming DL, Huntingford C, Jones CD, Sexton DM, Webb MJ (2007) Projected increase in continental runoff due to plant responses to increasing carbon dioxide. Nature 448(7157):1037-1041. doi:10.1038/nature06045

Beven K (1989) Changing ideas in hydrology-the case of physically based models. J Hydrol 105:157-172

Beven K (1993) Prophecy, reality and uncertainty in distributed hydrological modeling. Adv Water Resour 16:41-51

Bongio M, Avanzi F, De Michele C (2016) Hydroelectric power generation in an Alpine basin: future water-energy scenarios in a run-of-the-river plant. Adv Water Resour 94:318-331. doi:10. 1016/j.advwatres.2016.05.017

Brunetti M, Maugeri M, Nanni T, Auer I, Böhm R, Schöner W (2006) Precipitation variability and changes in the greater Alpine region over the 1800-2003 period. Int J Climatol 111(D11):D11107. doi:10.1029/2005JD006674

Brunetti M, Lentini G, Maugeri M, Nanni T, Auer I, Böhm R, Schöner W (2009) Climate variability and change in the Greater Alpine Region over the last two centuries based on multivariable analysis. Int J Climatol 29(15):2197-2225. doi:10.1002/ joc. 1857 
Edijatno Nascimento NO, Yang X, Makhlouf Z, Michel C (1999) GR3 J: a daily watershed model with three free parameters. Hydrol Sci J 44(2):263-277

EEA report 2012: European Environmental Agency (2012) Climate change, impacts and vulnerability in Europe 2012. ISBN 978-929213-346-7. doi:10.2800/66071

EU Green Paper (2007) Adapting to climate change in Europeoptions for EU action. Green Paper from the Commission to the Council, the European Parliament, the European Economic and Social Committee and the Committee of the Regions. Brussels. http://eur-lex.europa.eu/LexUriServ/site/en/com/2007/ com2007_0354en01.pdf

Farinotti D, Usselmann S, Huss M, Bauder A, Funk M (2012) The runoff evolution in the Swiss Alps: projections for selected highalpine catchments based on ENSEMBLES scenarios. Hydrol Process 26:1909-1924. doi:10.1002/hyp.8276

Fischer M, Huss M, Hoelzle M (2015) Surface elevation and mass changes of all Swiss glaciers 1980-2010. Cryosphere 9:525-540. doi: $10.5194 /$ tc-9-525-2015

Garrick M, Cunnane C, Nash JE (1978) A criterion of efficiency for rainfall-runoff models. J Hydrol 36:375-381

Giesecke J, Heimerl S, Mosonyi E (2014) Wasserkraftanlagen: Planung, Bau und Betrieb. Springer, Berlin

Gobiet A, Kotlarski S, Beniston M, Heinrich G, Rajczak J, Stoffel M (2014) 21st century climate change in the European Alps-a review. Sci Total Environ 493:1138-1151. doi:10.1016/j.scito tenv.2013.07.050

Gupta HV, Beven KJ, Wagener T (2005) Model calibration and uncertainty estimation. Part 11 Section 131 in Volume 3, Encyclopaedia of Hydrological Sciences. Wiley, Chichester, pp 2015-2032

Haeberli W, Beniston M (1998) Climate change and its impacts on glaciers and permafrost in the alps. Ambio 27(4):258-265. doi: $10.2307 / 4314732$

Haylock MR, Hofstra N, Klein Tank AMG, Klok EJ, Jones PD, New M (2008) A European daily high-resolution gridded dataset of surface temperature and precipitation. J Geophys Res 113(20):D20119

Heinrich G, Gobiet A, Mendlik T (2014) Extended regional climate model projections for Europe until the mid-twentyfirst century: combining ENSEMBLES and CMIP3. Clim Dyn 42(1-2):521-535. doi:10.1007/s00382-013-1840-7

Huss M (2011) Present and future contribution of glacier storage change to runoff from macroscale drainage basins in Europe. Water Resour Res. doi:10.1029/2010WR010299

Huss M, Hock R (2015) A new model for global glacier change and sea-level rise. Front Earth Sci 3:54. doi:10.3389/feart.2015. 00054

Jacob D, Petersen J, Eggert B, Alias A, Christensen OB, Bouwer L, Braun A, Colette A, Déqué M, Georgievski G, Georgopoulou E, Gobiet A, Menut L, Nikulin G, Haensler A, Hempelmann N, Jones C, Keuler K, Kovats S, Kröner N, Kotlarski S, Kriegsmann A, Martin E, Meijgaard E, Moseley C, Pfeifer S, Preuschmann S, Radermacher C, Radtke K, Rechid D, Rounsevell M, Samuelsson P, Somot S, Soussana J, Teichmann C, Valentini R, Vautard R, Weber B, Yiou P (2013) EURO-CORDEX: new highresolution climate change projections for European impact research. Reg Environ Change. doi:10.1007/s10113-013-0499-2

Kishor N, Saini RP, Singh SP (2007) A review on hydropower plant models and control. Renew Sust Energ Rev 11:776-796

Klein B, Krahe P, Lingemann I, Nilson E, Kling H, Fuchs M (2011) Assessing climate change impacts on water balance in the upper danube basin based on 23 member RCM Ensemble. In: Proceedings of the XXVth conference of the Danube countries, 16-17 Juni 2011, Budapest
Klemes V (1986) Operational testing of hydrological simulation models. Hydrol Sci J 31:13-24

Kling H, Fuchs M, Paulin M (2011) Ensemble Modellierung der Abflusscharakteristik der oberen Donau unter Klimaszenarien. Tag der Hydrologie, March 2011, Vienna

Klok EJ, Klein Tank AMG (2009) Updated and extended European dataset of daily climate observations. Int $\mathbf{J}$ Climatol 29(8):1182-1191

Kobierska F, Jonas T, Zappa M, Bavay M, Magnusson J, Bernasconi SM (2013) Future runoff from a partly glacierized watershed in Central Switzerland: a two-model approach. Adv Water Resour 55:204-214

Koch F, Prasch M, Bach H, Mauser W, Appel F, Weber M (2011) How will hydroelectric power generation develop under climate change scenarios? A case study in the Upper Danube Basin. Energies 4:1508-1541

Kotlarski S, Keuler K, Christensen OB, Colette A, Déqué M, Gobiet A, Goergen K, Jacob D, Lüthi D, van Meijgaard E, Nikulin G, Schär C, Teichmann C, Vautard R, Warrach-Sagi K, Wulfmeyer V (2014) Regional climate modeling on European scales: a joint standard evaluation of the EURO-CORDEX RCM ensemble. Geosci Model Dev 7(4):1297-1333. doi:10.5194/gmd-7-12972014

Kranzl L, Haas R, Kalt G, Müller A, Nakicenovic N, Redl C, Formayer H, Haas P, Lexer MJ, Seidl R, Schörghuber S, Nachtnebel HP, Stanzel P (2010) Ableitung von prioritären Maßnahmen zur Adaption des Energiesystems an den Klimawandel - "KlimAdapt"-Endbericht. Klima- und Energiefonds des Bundes, p 225

Krause P, Boyle DP, Bäse F (2005) Comparison of different efficiency criteria for hydrological model assessment. Adv Geosci 5:89-97

Kromp-Kolb H, Nakicenovic N, Seidl R, Steininger K, Ahrens B, Auer I, Baumgarten A, Bednar-Friedl B, Eitzinger J, Foelsche U, Formayer H, Geitner C, Glade T, Gobiet A, Grabherr G, Haas R, Haberl H, Haimberger L, Hitzenberger R, König M, Köppl A, Lexer M, Loibl W, Molitor R, Moshammer H, Nachtnebel HP, Prettenthaler F, Rabitsch W, Radunsky K, Schneider L, Schnitzer H, Schöner W, Schulz N, Seibert P, Stagl S, Steiger R, Stötter H, Streicher W, Winiwarter W (2014) Synthesis. In: Austrian assessment report climate change 2014 (AAR14), Austrian panel on climate change (APCC). Austrian Academy of Sciences Press, Vienna, pp 31-95

Laghari AN, Vanham D, Rauch W (2012) The Indus basin in the framework of current and future water resources management. Hydrol Earth Syst Sci 16:1063-1083. doi:10.5194/hess-16-1063-2012

Le Moine N, Andréassian V, Perrin C, Michel C (2007) How can rainfall-runoff models handle intercatchment groundwater flows? Theoretical study based on 1040 French catchments. Water Resour Res 43:W06428. doi:10.1029/2006WR005608

Lehner B, Czisch G, Vassolo S (2005) The impact of global change on the hydropower potential of Europe: a model-based analysis. Energy Policy 33:839-855

Loague K, Freeze RA (1985) A comparison of rainfall-runoff modeling techniques on small upland catchments. Water Resour Res 21:229-248

Lockwood JG (1999) Is potential evapotranspiration and its relationship with actual evapotranspiration sensitive to elevated atmospheric $\mathrm{CO}_{2}$ levels? Clim Change 41(2):193-212

Majone B, Villa F, Deidda R, Bellin A (2016) Impact of climate change and water use policies on hydropower potential in the south-eastern Alpine region. Sci Total Environ 543:965-980

Maran S, Volonterio M, Gaudard L (2013) Climate change impacts on hydropower in an alpine catchment. Environ Sci Policy. doi:10.1016/j.envsci.2013.12.001 
McVicar TR, Roderick ML, Donohue RJ, Li LT, Van Niel TG, Thomas A, Grieser J, Jhajharia D, Himri Y, Mahowald NM, Mescherskaya AV, Kruger AC, Rehman S, Dinpashoh Y (2012) Global review and synthesis of trends in observed terrestrial near-surface wind speeds: implications for evaporation. J Hydrol 416-417:182-205

Milly PCD, Betancourt J, Falkenmark M, Hirsch RM, Kundzewicz ZW, Lettenmaier DP, Stouffer RJ (2008) Stationarity is dead: whither water management? Science 319(5863):573-574. doi:10.1126/science. 1151915

Moriasi DN, Arnold JG, Van Liew MW, Bingner RL, Harmel RD, Veith TL (2007) Model evaluation guidelines for systematic quantification of accuracy in watershed simulations. Trans ASABE 50(3):885-900

Mouelhi S, Michel C, Perrin C, Andréassian V (2006) Stepwise development of a two-parameter monthly water balance model. J Hydrol 318(1-4):200-214

Nakicenovic N, Alcamo J, Davis G, de Vries B, Fenhann J, Gaffin S, Gregory K, Grubler A, Jung TY, Kram T, La Rovere EL, Michaelis L, Mori S, Morita T, Pepper W, Pitcher H, Price L, Raihi K, Roehrl A, Rogner HH, Sankovski A, Schlesinger M, Shukla P, Smith S, Swart R, van Rooijen S, Victor N, Dadi Z (2000) Emission scenarios. A special report of working group III of the intergovernmental panel on climate change. Cambridge University Press, Cambridge

Nash JE, Sutcliffe JV (1970) River flow forecasting through conceptual models, Part I-a discussion of principles. J Hydrol $10: 282-290$

OECD (2007) Climate change in the European Alps: adapting winter tourism and natural hazards management. OECD Publishing, ISBN: 97-64-03168-5

Okkan U, Fistikoglu O (2013) Using ECHAM5 general circulation model and hydrological lumped model GR2M to assess impacts of climate change on runoff. Digital Proceeding of the ICOEST 2013, Cappadocia

Oudin L, Hervieu F, Michel C, Perrin C, Andréassian V, Anctil F, Loumagne $\mathrm{C}$ (2005) Which potential evapotranspiration input for a lumped rainfall-runoff model? Part 2-towards a simple and efficient potential evapotranspiration model for rainfallrunoff modeling. J Hydrol 303:290-306

Oudin L, Andréassian V, Mathevet T, Perrin C, Michel C (2006) Dynamic averaging of rainfall-runoff model simulations from complementary model parameterizations. Water Resour Res 42(7):W07410. doi:10.1029/2005WR004636

Perrin C, Michel C, Andréassian V (2001) Does a large number of parameters enhance model performance? Comparative assessment of common catchment model structures on 429 catchments. J Hydrol 242:275-301

Perrin C, Michel C, Andréassian V (2003) Improvement of a parsimonious model for streamflow simulation. J Hydrol 279:275-289

Pöhler H, Wendel S, Schultze B, Karl S, Scherzer J (2010) Water balance modeling for the Inn River Basin. AdaptAlp technical report LfU-UDATA

Prein AF, Gobiet A, Truhetz H (2011) Analysis of uncertainty in large scale climate change projections over Europe. Meteorol Z 20(4):383-395. doi:10.1127/0941-2948/2011/0286

Raible CC, Casty C, Luterbacher J, Pauling A, Esper J, Frank DC, Büntgen U, Roesch AC, Tschuck P, Wild M, Vidale P, Schär C, Wanner H (2006) Climate variability-observations, reconstructions, and model simulations for the Atlantic-European and Alpine region from 1500-2100 AD. Clim Change 79:9-29. doi:10.1007/s10584-006-9061-2

Rajczak J, Pall P, Schär C (2013) Projections of extreme precipitation events in regional climate simulations for Europe and the Alpine Region. J Geophys Res 118:3610-3626. doi:10.1002/jgrd.50297
Rebora N, Silvestro F, Rudari R, Herold C, Ferraris L (2016) Downscaling stream flow time series from monthly to daily scales using an auto-regressive stochastic algorithm: streamFARM. J Hydrol 537:297-310. doi:10.1016/j.hydrol.2016.03. 015

Schaefli B (2015) Projecting hydropower production under future climates: a guide for decision-makers and modelers to interpret and design climate change impact assessments. WIREs Water 2:271-289. doi:10.1002/wat2.1083

Schaefli B, Gupta H (2007) Do Nash values have value? Hydrol Process 21:2075-2080. doi:10.1002/hyp.6825

Schaefli B, Hingray B, Musy A (2007) Climate change and hydropower production in the Swiss Alps. Quantification of potential impacts and related modeling uncertainties. Hydrol Earth Syst Sci 11(3):1191-1205

Schär C, Davies TD, Frei C, Wanner H, Widmann M, Wild M, Davies HC (1998) Current Alpine climate. In: Cebon P et al (eds) Views from the Alps: regional perspectives on climate change. MIT Press, Boston, pp 21-72

Schüppel A (2010) Modellierungsansätze zur Beschreibung dargebotsabhängiger Stromerzeugung. Master's thesis. Institute of Electricity Economics and Energy Innovation, Graz University of Technology

Sheffield J, Wood EF, Roderick ML (2012) Little change in global drought over the past 60 years. Nature 491(7424):435-438. doi:10.1038/nature 11575

Smakhtin VU (2000) Estimating daily flow duration curves from monthly stream flow data. Water SA 26(1):13-18

Stanzel P, Nachtnebel HP (2010) Mögliche Auswirkungen des Klimawandels auf den Wasserhaushalt und die Wasserkraftnutzung in Österreich. Österreichische Wasser und Abfallwirtschaft 62(9-10):180-187, ISSN 0945-358X

Taylor KE, Stouffer RJ, Meehl GA (2012) An Overview of CMIP5 and the Experiment Design. Bull Am Meteorol Soc 93(4):485-498. doi:10.1175/BAMS-D-11-00094.1

Tebaldi C, Knutti R (2007) The use of the multi-model ensemble in probabilistic climate projections. Philos Trans R Soc A 365:2053-2075. doi:10.1098/rsta.2007.2076

Themeß1 MJ, Gobiet A, Leuprecht A (2011) Empirical-statistical downscaling and error correction of daily precipitation from regional climate models. Int J Climatol 31(10):1530-1544

Themeß1 MJ, Gobiet A, Heinrich G (2012) Empirical-statistical downscaling and error correction of regional climate models and its impact on the climate change signal. Clim Change 112(2):449-468

Van Den Besselaar EJM, Haylock MR, Van Der Schrier G, Klein Tank AMG (2011) A European daily high-resolution observational gridded data set of sea level pressure. J Geophys Res Atmos 116:D11110

van der Linden P, Mitchell JFB (2009) ENSEMBLES: Climate Change and its Impacts: Summary of research and results from the ENSEMBLES project. Met Office Hadley Centre, Exeter

van Vuuren DP, Edmonds J, Kainuma M, Riahi K, Thomson A, Hibbard K, Hurtt GC, Kram T, Krey V, Lamarque J, Masui T, Meinshausen M, Nakicenovic N, Smith SJ, Rose SK (2011) The representative concentration pathways: an overview. Clim Change 109(1-2):5-31. doi:10.1007/s10584-011-0148-z

Vaze J, Post DA, Chiew FHS, Perraud J-M, Viney NR, Teng J (2010) Climate non-stationarity-validity of calibrated rainfall-runoff models for use in climate change studies. J Hydrol 394:447-457

Wagner T, Mayaud C, Benischke R, Birk S (2013) Ein besseres Verständnis des Lurbach-Karstsystems durch ein konzeptionelles Niederschlags-Abfluss-Modell. Grundwasser 18:225-235

Wagner T, Pauritsch M, Winkler G (2016) Impact of relict rock glaciers on spring and stream flow of alpine watersheds. Examples of the Niedere Tauern Range, Eastern Alps (Austria). Aust J Earth Sci 109(1):84-98. doi:10.17738/ajes.2016.0006 
Wilcke RAI, Mendlik T, Gobiet A (2013) Multi-variable error correction of regional climate models. Clim Change 120(4):871-887. doi:10.1007/s10584-013-0845-x

Xu CY, Seibert J, Halldin S (1996) Regional water balance modeling in the NOPEX area: development and application of monthly water balance models. J Hydrol 180:211-236
ZAMG/TU-Wien Studie (2011) Anpassungsstrategien an den Klimawandel für Österreichs Wasserwirtschaft. Endbericht, Lebensministerium 